\title{
Do In-Work Tax Credits Serve as a Safety Net?
}

\author{
Marianne Bitler \\ Department of Economics, UC Irvine and NBER \\ mbitler@uci.edu \\ Hilary Hoynes \\ Department of Economics, UC Davis and NBER \\ hwhoynes@ucdavis.edu \\ Elira Kuka \\ Department of Economics, UC Davis \\ ekuka@ucdavis.edu
}

April 2013

\begin{abstract}
:
The cash and near cash safety net in the U.S. has undergone a dramatic transformation in the past fifteen years. Federal welfare reform has led to the "elimination of welfare as we know it" and several tax reforms have substantially increased the role of "in-work" assistance. In 2010, we spent more than 5 dollars on the Earned Income Tax Credit (EITC) for every dollar spent on cash benefits through Temporary Assistance for Needy Families (TANF), whereas in 1994 on the eve of federal welfare reform these programs were about equal in size. In this paper, we evaluate and test whether the EITC satisfies a defining feature of a safety net program - that it responds to economic need. In particular, we explore how EITC participation and expenditures change with the business cycle. The fact that the EITC requires earned income leads to a theoretical ambiguity in the cyclical responsiveness of the credit. We use administrative IRS data from 1996-2008 to examine the relationship between business cycles and the EITC program. Our empirical strategy relies on exploiting differences in the timing and severity of economic cycles across states. The results show that higher unemployment rates lead to higher EITC caseloads and total dollar amounts of credits for married couples. On the other hand, the effect of business cycles on the size of the EITC program is insignificant for single individuals, whether measured by caseloads or expenditures. These patterns are consistent with static labor supply theory, and how economic shocks are likely to affect one versus two-earner households.
\end{abstract}

We thank Dan Feenberg for help with the NBER SOI data and Myrtis Herrod of IRS for providing us with tabulations of the EITC for the most recent period. We also thank Janet Holtzblatt, Jeff Liebman, Laura Wheaton, and Ed Harris for help with constructing the "at-risk" population to accompany the data from SOI tax filing units. 


\section{Introduction}

The Earned Income Tax Credit provides a refundable tax credit to lower income working families through the tax system. As a consequence of legislated expansions in the EITC and the dismantling of welfare through the 1996 welfare reform, the EITC is now the most important cash transfer program for these families (Bitler and Hoynes 2011). In 2010, the EITC reached 27.8 million tax filers at a total cost of $\$ 60.9$ billion. Almost 20 percent of tax filers receive the EITC, and the average credit amount is $\$ 2,194$.

One feature of a safety net program is that it raises incomes at the bottom of the income distribution. Using this definition, the EITC is the most important safety net program for low-income families with children: the recent release by the U.S. Census of the Supplemental Poverty measure reveals that in 2011 the EITC lifted 4.7 million children from poverty, more than any program (Short 2012) ${ }^{1}$. Among all persons in the U.S. there is only one government program that lifts more persons from poverty - Social Security (Short 2012).

A second key feature of a safety net is that protection increases in times of need. For example, a negative shock to family earnings as a result of job loss is mitigated by social insurance benefits (e.g., unemployment compensation) as well as public assistance benefits (e.g., food stamps). These programs are designed to reduce income volatility. This feature of the EITC has not been explored and is the focus of our work.

To examine this issue, we use high quality administrative data on tax returns from the Internal Revenue Service. We focus on estimating the relationship between business cycles and the size of the EITC program. Our empirical strategy relies on exploiting differences in the timing and severity of economic cycles across states. We measure the business cycle using the state unemployment rate in a panel fixed effects model.

A defining feature of the EITC, and a general characteristic of "in-work" assistance programs, is that positive earnings are required for eligibility for the tax credit. The prior literature

\footnotetext{
${ }^{1}$ This calculation includes the combined anti-poverty effects for the EITC and the child tax credit.
} 
has established that the EITC has led to sizable increases in the employment rates of single mothers (Eissa and Liebman 1996, Meyer and Rosenbaum 2000, 2001), yet has led to modest reductions in the employment of married women (Eissa and Hoynes 2004). Given the earnings requirement at the center of EITC eligibility, the response of the EITC to cycles (and economic need) is theoretically ambiguous. On the one hand, a downturn may lead to higher EITC participation - if downturninduced decreases in earnings move taxpayers into the EITC eligibility range for income. On the other hand, a downturn could lead to lower EITC participation - if downturn-induced decreases in employment bring earnings to zero.

Our estimates suggest that the net effect of these two changes varies across different family structures. We find that higher unemployment rates lead to higher EITC caseloads and total dollar amounts of credits for married couples with children. ${ }^{2}$ This suggests that for married couples, an adverse labor market shock causes them to move to a lower level in the earnings distribution relative to where they would have been absent the shock, leading to more participation in the program. The effect of business cycles on the EITC is insignificant for single tax filers with children, whether measured by caseloads or expenditures. This is consistent with expectations for a "one earner" labor supply model - whereby job loss would eliminate family earnings thus reducing EITC participation.

Our main results use data for 1996-2008; 2008 being the last year that the IRS Statistics of Income micro data is available. We collapse this data to cells defined by state, tax year, marital (filing) status, and number of children. We then estimate models separately for these different demographic groups. Using more aggregated data we are able to extend this analysis through 2010, enabling the capture of the full Great Recession period. The results are similar for this period as for our main sample spanning 1996-2008.

To put these results in context, we compare our results to estimates of the cyclicality of other

\footnotetext{
${ }^{2}$ Throughout our analysis, all caseload and expenditure data are expressed relative to a population denominator. For the central EITC results, the populations are the total within-cell number of potential tax filing units calculated from the CPS ASEC. When we compare results across safety-net programs, however, we use the total population of persons in each state and year as the denominator. Details are provides below.
} 
key safety net programs including Unemployment Compensation, Food Stamps, and TANF. Our estimates imply that a 1 percentage point increase in the unemployment rate leads to a 6.3 percent increase in EITC caseloads for the married couples with children (table 2). Single filers without children, who are eligible for a much smaller credit, also exhibit counter-cyclical movements - a one percentage point increase in the unemployment rate leads to a 3.2 percent increase in caseloads. The largest group of recipients, single filers with children, shows small negative (pro-cyclical) but insignificant responses to the unemployment rate. Overall, pooling all EITC recipients, the caseload is modestly counter-cyclical, with a one percentage point increase in the unemployment rate leading to a 2.3 percent increase in caseloads (table 4). We show that the EITC exhibits less countercyclical movements than TANF, Food Stamps, and unemployment compensation. Our results, estimating similar models for the same time period, show that a one percentage point increase in the unemployment rate leads to an increase in caseloads of 8.4 percent for Food Stamps, 7.7 percent for TANF, and 14.5 percent for Unemployment Insurance payments (UI).

As a second way to put these results in context, we use the March Current Population Survey to explore how the EITC affects the cyclicality of income. In particular, we estimate the effects of unemployment on poverty rates, using similar state panel data models. Our baseline results use an alternative poverty measure, similar in its measurement of resources to the new Supplemental Poverty Measure, that we are able to consistently measure throughout our analysis period. This alternative poverty measure expands the definition of income to include non-cash government benefits and taxes (Bitler and Hoynes 2010). We then recalculate poverty eliminating the EITC (in a static sense; nothing else in the household changes). Consistent with the SOI analysis, poverty fluctuates less across the business cycle due to the EITC, with the strongest protective element among married couples with children.

These results are valuable for several reasons. First, the Great Recession is the first "test" of our safety net in the post-welfare reform era (Bitler and Hoynes 2010). Given the recent decrease in traditional welfare programs (TANF) that acted as automatic stabilizers, it is important to understand 
how this recession is affecting the American population and poverty. Secondly, as many OECD countries adopt similar in-work policies (Owens, 2005), understanding the effect of business cycles on in-work programs is fundamental for policy makers' decision making and budget planning.

The remainder of this paper proceeds as follows. Section 2 outlines the EITC and the recent evolution of the safety net and discusses the theoretical predictions. Section 3 discusses the data and Section 4 presents our empirical model. The results are presented in Section 5, sensitivity analysis is in Section 6, and we conclude in Section 7.

\section{The EITC, the Prior Literature, and Theoretical Predictions}

The U.S. safety net for low-income families has undergone a dramatic transformation in the past fifteen years. Many aspects of this transformation are illustrated in Figure 1. In this figure, we plot real per capita expenditures from 1980 to 2011 (2010 for the EITC) for the three main cash or near-cash programs for low-income families with children: the EITC, Temporary Assistance for Needy Families (TANF), and Food Stamps (now called SNAP or Supplemental Assistance for Needy Families). The shaded regions are contractionary periods, annualized periods based on the NBER recession dates. ${ }^{3}$

The expansion of the EITC between 1986 and 1998, coupled with the decline in cash welfare expenditure beginning with the welfare waivers of the early 1990s and continuing through the 1996 federal welfare reform, led to the rise in the importance of the EITC and a fall in the importance of cash welfare (TANF). By 2010, spending on the EITC was almost five and a half dollars for every dollar on TANF cash benefits (in 1994, on the eve of federal welfare reform, these programs were about equal in size). This evolution represents a tremendous change in the safety net for low-income families with children - a transformation from out-of-work aid (welfare) to in-work aid (EITC).

As is suggested by Figure 1, the EITC is now one of the most costly cash or near-cash safety

\footnotetext{
${ }^{3}$ The official NBER recession dating is monthly; this figure presents annual data. We constructed an annual series for contractions based on the official monthly dates, augmented by examination of the peaks and troughs in the national unemployment rate. See Bitler and Hoynes (2010) for more information on the annual dating.
} 
net programs for low-income families with children. In 2010, the most recent year for which data are available, the EITC was received by 26 million families (or more accurately tax filing units, which can include single individuals as well), at a cost of almost $\$ 60$ billion. This amounts to an average credit of about $\$ 2,240$ (IRS 2011).

The EITC is distributed through the federal tax system, and the goal is to increase after-tax incomes of lower earning taxpayers, primarily those with children, while incentivizing work. The EITC schedule has three regions. In the first, called the phase-in region, the credit is phased in at a constant rate: for each dollar earned, the taxpayers currently receive $34-40$ cents in the credit. In the second region, the flat region, the taxpayers receive the maximum amount of EITC benefit. In the phase-out region, the credit is phased out at a constant rate: taxpayers lose 16-20 cents for each extra dollar earned. Figure 2 illustrates the relationship between earned income and the EITC for the largest group of recipients, single filers with two children. The $\mathrm{x}$-axis is annual earned income and the y-axis is the 2012 EITC. The potential income transfer is substantial - the maximum credit is $\$ 5,236$ and the phase-out range extends to earned income of $\$ 41,952$. There are separate schedules for taxpayers depending on the number of children, and in some years, marital status. ${ }^{4}$ Importantly, individuals without children are eligible for a very small credit. ${ }^{5}$

Enacted in 1975, the EITC has been expanded by tax legislation several times in the subsequent years $(1986,1990,1993,2001$, and 2009). Although the basic shape of the EITC schedule has remained the same (as in Figure 2), these various expansions led to changes in the credit's rates in both the phase-in and phase-out regions as well as changes in the maximum EITC benefit. Figure 3 illustrates the changes to the EITC over time. In particular, we plot the real maximum credit by year and number of children for each year between 1983 and 2012. The 1993

\footnotetext{
${ }^{4}$ Beginning in 2002, the phase-out range was increased for married taxpayers filing jointly. In 2012, the values for these taxpayers are about $\$ 5,000$ higher than for singles. This has been expanded over time; for example it was $\$ 1,000$ higher than for singles in 2002-2004 and \$2000 higher in 2005-2007.

${ }^{5}$ Adjusted gross income (AGI) also plays a role in calculating EITC eligibility and benefits. First, AGI must also be less than the end of the phase-out region. Second, for filers in the phase-out region, their credit is the lower of the credit calculated based on earned income and the credit based on AGI. When we analyze EITC eligibility (e.g. Table 3 and Figure 4 below) we use only earned income and do not impose the AGI requirement. For more information on the EITC program, see Eissa and Hoynes (2006) and Hotz and Scholz (2003).
} 
expansion is the most significant, introducing the relatively small credit for childless taxpayers and a second higher benefit schedule for those with two or more children compared to those with one child. The 2009 expansion, introduced as part of the federal stimulus, introduced a separate even higher schedule for those with three or more children.

Table 1 provides summary statistics for 2008 , the most recent tax year in the micro SOI data (the data is discussed more fully below). In 2008 there were 24.4 million tax returns with an EITC for a total cost of $\$ 50.5$ billion. This represents 18.6 percent of the total tax returns filed that year. The table shows that the recipients are split between single with children (58.7\%), married with children (19.4\%) and taxpayers without children (21.9\%). In 2008, the average credit per filer was $\$ 2,613$ for single parents with children, $\$ 2,471$ for married couples with children, and $\$ 253$ for childless individuals. Overall the majority of the dollars spent on the program go to families with children: $74.1 \%$ for single filers with children and $23.2 \%$ for married filers with children. The small share of dollars claimed among those without children $(2.7 \%)$ reflects their lower possible and actual credit amounts.

A substantial literature uses the EITC expansions to estimate the impact of the credit on labor supply. Among single-earner families with children, labor-supply theory predicts an increase in employment. However, hours of work (earnings) for those already in the labor market are predicted to decline. ${ }^{6}$ Because the EITC is based on family income, the credit leads to a very different set of incentives for married taxpayers. Among secondary earners in married couples, the EITC is expected to reduce employment and hours worked for those already in the labor force (Eissa and Hoynes 2004). The prior literature provides consistent and robust evidence that the EITC increases employment of single mothers (Eissa and Liebman 1996, Meyer and Rosenbaum 2000, 2001). Additionally, the research shows that the EITC leads to modest reductions in the employment of

\footnotetext{
${ }^{6}$ The prediction depends where the taxpayer is in the EITC schedule. If she is in the phase-in region, the EITC leads to an ambiguous impact on hours worked due to the negative income effect and positive substitution effect. In the flat region and phase-out region, the EITC leads to an unambiguous reduction in hours worked. Moreover, some taxpayers with earnings beyond the phase-out region may choose to reduce their hours of work and take advantage of the credit.
} 
married women (Eissa and Hoynes 2004). There is less evidence supporting the prediction of a negative intensive margin (hours, earnings) response (for a review see Eissa and Hoynes 2006). Work by Saez (2010) and Chetty et al. (2013) suggests intensive margin adjustments for some workers.

In addition, because the EITC is tied to marital status and the presence and number of children, an expansion in the credit could theoretically lead to changes in these demographic outcomes. The research, however, suggests that the EITC does not impact fertility (Baughman and Dickert-Conlin, 2009) or family formation (Dickert-Conlin 2002; Ellwood, 2000, Herbst 2011). ${ }^{7}$ Recent work shows that the EITC has important effects beyond income and earnings; EITC-induced additional family income leads to improvement in maternal and infant health (Hoynes et al., 2012, Evans and Garthwaite 2010, Baker 2008) and children's cognitive achievement (Dahl and Lochner 2012).

We contribute to the literature by evaluating and testing whether the EITC satisfies a defining feature of a safety-net program - that its use responds to economic need. In particular, we explore how EITC participation and expenditures change with the business cycle. This focus links our paper to the empirical literature on the cyclicality of safety-net programs such as food stamps (e.g., Ziliak et al., 2003, Bitler and Hoynes 2010), AFDC/TANF (Blank 2001, Ziliak et al., 2000, Bitler and Hoynes 2010) and other food and nutrition programs (Corsetto 2012).

Unlike predictions about how the AFDC/TANF, unemployment compensation, and food stamps respond to economic downturns, theoretical predictions about the effect of cycles on the EITC are ambiguous. As discussed above, eligibility for the EITC requires that earnings are strictly greater than zero and less than the end of the phase-out range. On the one hand, a downturn may lead to higher EITC participation - if decreases in earnings move taxpayers down into the EITC eligibility range. On the other hand, a downturn could lead to lower EITC participation - if a decrease in

\footnotetext{
${ }^{7}$ This finding is consistent with the broader literature finding that the elasticity of fertility with respect to transfers from income support programs is very small (Moffitt 1998).
} 
employment reduces earnings to zero. These two possibilities are illustrated on Figure 2, presented earlier, which shows the EITC schedule for single filers with two children. One arrow shows a reduction in earnings that moves a family into the EITC eligible range; we label this arrow with a "+" to indicate that this movement leads to an increase in EITC participation. A second arrow shows a reduction in earnings that moves a family out of the EITC eligible range (reducing earnings to zero $\rightarrow$ loss of eligibility for EITC; in addition the family may not file taxes which would also reduce the number of tax filers); we label this arrow with a "-_" to indicate that this movement leads to a decrease in EITC participation. The third arrow illustrates a reduction in earnings, but one that takes place within the EITC eligible range, leading to a " 0 " impact on participation.

Figure 4 serves to sharpen these theoretical predictions for the demographic groups of interest. Here we present histograms for tax-return reported earned income in 2006, the "peak" year prior to the Great Recession. We present the histograms for six demographic groups that correspond to the different EITC schedules: single no children, married no children, single one child, married one child, single two + children and married two + children. For each, the dashed line shows the EITC schedule and we force the $\mathrm{x}$ - and y-axes to have the same scale across all 6 graphs. We limit the sample in each case to those returns with earned income between $\$ 1$ and $\$ 60,000$. Note that we do not condition on the receipt of the EITC, but tabulate earned income and see how it intersects with the EITC eligibility range. ${ }^{8}$ On each graph we also indicate the share of the total filers for the demographic group that are excluded from the histogram (earned income is $<=0$ or $>\$ 60,000$ ). Several observations can be drawn from these figures. First, they well illustrate the variation in the generosity of the schedule across these six groups. Second, the distribution of earned income for single families with children is shifted to the left of the distribution for married families with children. Only $29.1 \%$ of singles with one child and $17.8 \%$ of singles with two children have earnings

\footnotetext{
${ }^{8}$ Our eligibility determination is not exact. First, as we discuss more below, a tax filer without children must be between the ages of 25 and 64 to receive the EITC. We do not observe age in our tax data (nor the flag for aged dependent status). Thus many in the tabulation for filers without children in fact are ineligible for the EITC because they are older than 64 or younger than 25 . Additionally, as mentioned above, for some taxpayers eligibility also depends on AGI and here we only use earned income.
} 
above the phase-out range (compared to $75.9 \%$ and $74.6 \%$ for married families with one and two children). Third, consistent with Saez (2010), there is evidence of clustering at the first kink of the EITC schedule for single families with children.

In addition to the labor supply channel, it is possible that our results could also capture effects operating through the cyclicality of marriage and fertility. Schaller (2012), for example, estimates that an increase in state unemployment rates leads to small declines in both marriage and divorce rates (between 1.5 and 1.7 percent), with evidence that the marriage effects are permanent while the divorce effects are more temporary. This "endogenous marital status" would operate against the expected labor supply channel - an increase in unemployment would lead to a reduction in the stock of married families which would potentially decrease EITC married filers and increase EITC single filers. The literature on the cyclicality of fertility is more mixed, but many studies document a negative effect of unemployment rates on fertility (e.g. Dehejia and Lleras-Muney 2004, Schaller 2013). These issues are particularly important to consider when we stratify our analysis by marital (filing) status, where a clean interpretation requires that the composition of the sample is not changing with the changes in the unemployment rate. In part to address this issue, we normalize the EITC caseloads and expenditures by the population of potential filers (by marital status and number of children). Further, when we estimate models for the full, pooled, EITC caseload, this issue is less important. Overall, our view is that the potential for endogenous changes in marriage and fertility is likely quite small relative to the changes in labor supply (across the cycle). ${ }^{9}$

In sum, we expect that the effect of a downturn on EITC participation is likely to vary by family structure. Singles with children, due to their single-earner status and their relatively low earnings, are at higher risk of losing the EITC in the event of an adverse labor market shock. On the other hand, given the higher level of earnings among married couples combined with the presence of two potential earners, an adverse labor market shock is more likely to lead to an increase the number

\footnotetext{
${ }^{9}$ We can use the administrative tax data to analyze the change in the composition of filers and EITC recipients by marital status and number of children. This can give us direct evidence within our sample about the importance of these channels.
} 
of married families with earnings in the EITC-eligible range. On net, therefore, we expect marriedcouple EITC caseloads to be more counter-cyclical than single-parent EITC caseloads (which may even be pro-cyclical).

\section{Data}

To empirically analyze the effect of business cycles on the size of the EITC, we utilize data from a variety of sources. Our primary data are administrative data from the IRS compiled from tax returns. The Statistics of Income (SOI) is a nationally representative sample of federal income tax returns. This is an annual cross-section, available for years 1979-2008. There are approximately 104,300 observations per year on average and these data are representative of all tax filers, and also of EITC claimants. The SOI data contain sample weights that allow us to infer results about the U.S. population of tax filers as a whole. The SOI data is limited to information on the federal tax return. We use information on filing status (single, head of household, married filing jointly, married filing separately), number of dependents, earned income, EITC credit amount, number of children qualifying for the EITC, and state of residence.

Our research design, discussed below, leverages variation in the timing and severity of business cycles across states. Thus, unlike much of the EITC literature, we do not leverage variation in the generosity of the EITC. In fact, we seek to analyze a period with minimal changes to the EITC. Thus, our main estimates rely on data for the tax years 1996 to 2008, to avoid the major confounding EITC expansions that occurred in the early 1990s. Figure 3, presented above, shows the relative stability of the EITC over this period. ${ }^{10}$ However, in the sensitivity checks, we examine the full time period covered by the SOI.

We end our sample period in 2008 because this is the last year for which the SOI micro data

\footnotetext{
${ }^{10}$ During the period we analyze, some minor expansions of the EITC still occurred. For example, as discussed above, the phase-out region for married couples with children was extended beginning in 2002. Additionally, in 2001 a "modified" AGI measure was replaced with AGI for analysis of eligibility and benefits in the phase-out region. In our analysis, time dummies will absorb the overall effects of expansions.
} 
are available. This is unfortunate given that we miss the full extent of the Great Recession. We were able to obtain summary data on EITC claims, by state and filing status (single, head of household, married), for 2009-2010. We use this to estimate more aggregated models using data through 2010. We discuss this below. ${ }^{11}$

Our sample is created as follows. First, we exclude all high-income individuals (filers with returns over $\$ 200,000$ of AGI), whose state identifiers are not reported in the SOI data because of issues of confidentiality. This sample exclusion is not problematic because these high-AGI filers have income far beyond the EITC eligibility range ${ }^{12}$. Second, we exclude individuals from Puerto Rico, Virgin Islands, Guam or U.S. citizens living abroad, as well as military personnel stationed abroad. In the data, these filers all have the same geographic identifier in the SOI data, making it impossible for us to assign them to the labor market conditions that they face. Moreover, we drop late filers, who are individuals filing tax returns in one year but with the return corresponding to some previous tax year. By dropping late filers, we exclude 59,835 observations from our main 1996-2008 sample, which represent around $2.8 \%$ of the weighted sample. In a robustness check, we analyze whether our results are sensitive to this sample restriction. Finally, we exclude married individuals filing separately, since these filers are not eligible for the EITC. For consistency, we exclude these individuals both from the EITC caseloads and expenditures analysis and from the total tax filers analysis.

After these sample restrictions, and for the majority of our empirical analysis, we collapse the data to cells based on year, state, marital status (married or single) and number of children (zero, one, or two or more). ${ }^{13}$

\footnotetext{
${ }^{11}$ These summary data are based on a sum of zipcode level data where zipcodes with fewer than 10 EITC recipients are suppressed. Thanks to Myrtis Herrod of the IRS for this data.

${ }^{12}$ Dropping this group could affect the estimates, presented below, for "total filers."

${ }^{13}$ The tax data identify filing status as married filing jointly, head of household, or single (and marred filing separately which we drop). We assign taxpayers to be married if they file married filing jointly, and single if the filer declared he/she was single or a head of household (meaning single with dependent children). The variable for the number of children takes the values 0,1 or 2, according to how many children the filers declare for EITC purposes. When tabulating total filers we use the number of child dependents $(0,1,2+)$ to assign the observations to the appropriate cells; we must do so as there is no number of EITC qualifying children for the non-EITC cells.
} 
After this collapse of the data, we have a total of 3,978 cells in our 1996-2008 sample (50 states plus DC times 13 years times 6 filing status/number of children groups). For each cell, we calculate the total number of filers, the total number of filers claiming the EITC, and the total amount of EITC benefits received; all as the weighted sums of these variables for each return in the cell, using the sample weights provided in the SOI data.

To put our analysis of the tax data in context, we bring two additional sources of data to our analysis. First, we use the March Current Population Survey to explore how the EITC affects the cyclicality of income and poverty. The March CPS (or Annual Social and Economic Supplement to the Current Population Survey) is administered to most households in March and collects labor market, income, and program participation information for the previous calendar year, as well as demographic information from the time of the survey. The sample size is approximately 150,000 persons or 57,000 households per year. We begin by splitting up the CPS sample into the same six demographic groups used in the SOI. Thus we identify families and assign them based on marital status and number of children. Following the filing rules, we count a child as a dependent if they are less than or equal to 19 or a full time student and less than or equal to 24 . In addition, to receive the EITC as a childless filer, a tax filer must be between 25 and 64. We limit the CPS analysis for the childless to those $25-64$.

We use the CPS to examine how the EITC affects the cyclicality of income and poverty, examining whether families have income below $50 \%, 100 \%, 150 \%$, and $200 \%$ of the federal poverty line. Official poverty status in the U.S. is determined by comparing total pre-tax family cash income to poverty thresholds, which vary by family size, number of children, and presence of elderly persons. In 2012, for example, the poverty threshold for a family of three (one adult, two children) was $\$ 18,498$. Notably, official poverty does not reflect the tax system (e.g., the EITC) or the noncash transfer system (e.g., food stamps).

Because of the narrowness of the official poverty measure, we instead use an alternative poverty measure which we developed using data provided in the public-use CPS data and available 
on a consistent basis back to 1980 (Bitler and Hoynes 2010, 2013). We developed this measure based on the recommendations in the National Academy of Sciences report (Citro and Michael, 1995); it is also closely related to the Supplemental Poverty Rate first released in 2010 (Short 2011, 2012). ${ }^{14}$ In particular, we assign poverty using an expanded "alternative income" measure which we then apply to the standard poverty thresholds. Our alternative income measure (or a measure of resources) adds to cash money income the cash value of non-cash programs (food stamps, school lunch, housing subsidies, energy subsidy, Medicaid, and Medicare), federal employee retirement benefit contributions and the implied rental value of an owner occupied home, and subtracts taxes (FICA payroll taxes, property taxes, net federal and state taxes [including the EITC]). ${ }^{15}$ We then analyze a second set of poverty measures where we "zero out" the EITC, recalculate alternative family income, and recalculate poverty. This is a "static" calculation in that is assumes nothing else changes in the family. We assign family characteristics, including marital status, using the values of the head of the family. ${ }^{16}$

We also use March Current Population Survey to create population estimates for denominators for our SOI analysis. We use this to convert the tax data to rates - EITC caseload per population (of potential filers, henceforth population) and EITC dollars per population (of potential filers ) - for each state-year-marital status-number of children cell. We construct the population denominators to reflect counts of the "at risk" population of potential tax filers (family units/single individuals relevant for claiming EITC). We use the same procedure as described above to divide the CPS sample into our demographic groups of interest—-single versus married, and presence of

\footnotetext{
${ }^{14}$ The Supplemental Poverty Measure (Short 2011, 2012) also incorporates other measures into its family resource measure to account for other large categories of expenses (e.g., out of pocket medical expenses, child care, and fixed costs of work, child support) and allows the thresholds to vary with geographic area and by expenditures on housing, food, clothing, and utilties. and with an eqivalence scale for various different units. The SPM also makes alternative choices about what a unit that shares resources is. We cannot use the SPM measure for our analysis, however, as it is unavailable in public-use micro data before 2010 .

${ }^{15}$ We constructed this alternative measure ourselves, based on data in the public use March CPS files, to be as consistent over time as possible while including as many components of CPS experimental poverty measures as possible (e.g., Dalaker, 2005).

${ }^{16} \mathrm{We}$ weight each unit by the weight of the individual denoted as the head (if a family/subfamily) or the weight of the individual themselves (for the unrelated childless filers).
} 
children $(0,1$, two or more). As above, to reflect the age restriction for eligibility for the EITC for childless taxpayers, we limit the single without children sample to those aged 25-64. We use the CPS March person weight for potential tax unit heads to aggregate these counts of family/potential filing unit heads to population counts of the same concept. ${ }^{17}$

To put our results on the cyclicality of the EITC in further context, we estimate similar models for other safety net programs including AFDC/TANF, Food Stamps, and Unemployment Insurance (UI). As with the EITC, we measure administrative counts of caseloads (here at the stateyear level) that cover the same time period as our core SOI results. We choose to normalize the caseloads by state total population, given the differences in eligibility determinations and units across programs. The AFDC/TANF and Food Stamps caseloads are average monthly measures (of families), while the UI data represent total population probability of being on UI on a weekly basis (total weeks of any UI benefits claimed divided by 52 weeks times state population). The data can be found at DHHS (2013), USDA (2013) and DOL (2010).

Finally, we merge the SOI, CPS and program caseload data per population (of potential filers) with state annual unemployment rates, the main explanatory variable in our regressions; they are obtained from the Bureau of Labor Statistics. Lastly, to control for potential confounders from state safety-net programs, we include data on state Medicaid/SCHIP income eligibility thresholds as well as dummies for the presence of state EITC programs or other state welfare reforms, and where relevant, dummies for demographic group.

\section{Empirical Strategy}

Our empirical strategy exploits variation in the timing and severity of cycles across states to

\footnotetext{
${ }^{17}$ We find that the number of single filers with children in the CPS is significantly below the number of single filers with children in the tax records. Others have noted this difference, which may reflect complicated living arrangements (children moving between custodial parents during the year) or noncompliance. Following others, we adopt an expansive definition where (following the filing rules) we identify children as individuals 19 or younger, or individuals 24 or younger that are full time students. Moreover, we identify as children also individuals that are not participating in the labor force because of disability. We explore the sensitivity to how we construct these denominators in Appendix Table 3, finding it makes very little different in the estimates (or in the state-level population totals, not shown).
} 
estimate the causal effect of labor market conditions on use of the EITC. Specifically, we measure the business cycle using the state unemployment rate. We start with the following pooled model:

$$
y_{g s t}=\beta \cdot U N_{s t}+\theta_{g}+\alpha_{s}+\delta_{t}+Z_{s t} \pi+y e a r_{t} \cdot \gamma_{s}+\varepsilon_{g s t}
$$

where subscripts refer to demographic cell $g$ (filing status x number of children $[0,1,2+]$ ), state $S$, and year $t . U R_{s t}$ is the state unemployment rate and $\theta_{g}$ are demographic group-specific intercepts. Our primary dependent variable is the EITC participants per relevant population (ratio of EITC participants to our CPS measure of population of potential tax filers, both for group $g$ ). We also examine EITC expenditures and filers per population of such filers (overall and in ranges of the EITC credit). We cluster standard errors at the state level, and the regressions are weighted by the denominators (potential filer population at the state-year-demographic group level).

Equation (1) contains controls for state and year fixed effects, $\alpha_{s}$ and $\delta_{t}$ respectively. By adding year fixed effects we absorb changes in the EITC that are due to national business cycles. This approach is necessary because it allows us to differentiate between changes in EITC due to labor market conditions and changes due to national EITC expansions, program take-up rates, and other national level confounders. Our main coefficient of interest is $\beta$, which represents the effect of the state unemployment rate on the EITC. If the estimate of $\beta$ is positive, it implies that the EITC is countercyclical and therefore during a recession, the EITC acts as an automatic stabilizer in the economy. If $\beta$ is negative, it implies that the EITC is pro-cyclical.

To explore the theoretical predictions, we analyze models stratified by demographic group. For example, single individuals may lose their jobs during recessions, thus losing EITC eligibility, while married couples may switch from being two-earner families to single-earner families (or experience some other reduction in family earnings), leading to increases in EITC use. To test these predictions, we separately estimate equation (1) for our main three groups of interest: childless individuals, single parents, and married parents. 
In order to control for possible confounders at the state-year level, in some specifications, we include various state-level measures of the safety net and the state-level EITC. The vector $Z_{s t}$ includes measures of state welfare reform, indicators for the presence of state EITC programs, and state Medicaid/SCHIP income eligibility thresholds. Additionally, we explore the sensitivity of the findings to controlling for state-specific linear time trends $\left(\gamma_{s}\right)$.

Similar models are estimated for our analysis of poverty rates and other program caseloads.

\section{Results}

Table 2 presents our main results. Column 1 presents estimates for the pooled sample, while the remaining columns are estimates stratified by our three demographic groups. The pooled sample contains 663 observations (data is collapsed to the state year level) while the other columns have 1326 observations. ${ }^{18}$ Panel A presents estimates for the EITC caseload and Panel B presents estimates for EITC expenditures (in real 2008 dollars). All regressions include state and year fixed effects. Moreover, all regressions but the pooled estimates include fixed effects for demographic characteristics. All models are clustered on state.

The results for the pooled sample show that a one percentage point increase in the state unemployment rate leads to a statistically significant 0.4 percentage point increase in EITC participation. For each regression (here and the tables below), we include the mean of the dependent variable and the "Percent Impact" which is calculated as the coefficient on the unemployment rate divided by the mean of the dependent variable. For the pooled sample, the one percentage point effect translates to 1.8 percent impact on caseloads. The effect on total EITC dollars is also positive, with a one percentage point increase in unemployment rate leading to a 1.2 percent increase in per capita expenditures, although this coefficient is statistically insignificant. These results suggest that,

\footnotetext{
18 The pooled sample is constructed by collapsing the numerator (EITC) and denominator (population) and creating the ratio of the two. The stratified samples have double the observables because each contains two demographic cells. The childless includes cells for married and singles, and the with-children groups includes cells for one and two or more children.
} 
overall, the EITC program is weakly countercyclical, providing additional resources in economic downturns.

The remaining columns of Table 2 present results for our three main subsamples: childless individuals, single parents, and married parents. Column 4 shows that the EITC program is strongly countercyclical for married parents, both measured by caseloads and by total dollar amounts. A one percentage point increase in the state unemployment rate leads to a 6.3 percent increase in caseloads and a 5.9 percent increase in total credit received with estimates significant at the 1 percent level. In addition, EITC caseloads are estimated to be countercyclical also for childless individuals (Column 2) - a one percentage point increase in unemployment leading to a 3.2 percent increase in per capita caseloads (significant at the 10 percent level). In contrast, the largest group of EITC participants, single parents, shows negative, but statistically insignificant coefficients. These results, taken at face value, suggest pro-cyclical movements and no automatic-stabilization for single parent families. In Appendix Table 1, we provide more detail by estimating models separately for all six demographic groups (single/married, by zero/one/two or more children). Those results show similar responses for families with one and two or more children. They also show that the childless results are primarily driven by single filers.

We also estimated models that allowed for differential effects in expansions and recessions. In all cases we could not reject that the coefficients where the same for the two periods, suggesting no evidence in favor of asymmetric responses (Appendix Table 2).

The differential patterns by marital status are illustrated in another way in Figure 5. Each panel provides a scatterplot where the observations are at the state level (where the size of the circle is weighted to reflect the state's population of possible filers). The horizontal axis in each panel denotes the change in state annual unemployment rates (in percentage points) between 2000 and 2008 and the vertical axis the change in state EITC caseloads per population (in percent) over the 
same period. ${ }^{19}$ We also include the linear fit (using the state-potential filer population as weights). We present these scatterplots for four groups: the pooled sample, childless filers, single parents with children, and married couples with children. The figure reveals considerable variation in labor market changes across states - the 2000 to 2008 change ranges from -1.2 percentage points (for WV) to a change of about 4.6 percentage points (for MI). Consistent with the regressions, the figures show a positive relationship between the severity of the unemployment rate increase and EITC caseloads for married couples and childless filers. Single parents with children, however, exhibit a negative relationship with rising unemployment rates associated with declining EITC caseloads.

These results are consistent with our theoretical predictions of the effect of local market conditions on the EITC program by family type. Figure 4, presented above, illustrates that only a relatively small share of the total filing population of single parents with children have incomes above the EITC phase-out range. With such a large share of the distribution within the EITC eligibility range, it is likely that a negative labor market shock will lead to no change in eligibility (a reduction in earnings within the eligibility range) or a reduction in eligibility (due to job loss and earnings falling to zero). On the other hand, among married families with children, far more than half the distribution lies above the phase-out range. A labor market shock to this group, therefore, would be much more likely to lead to an increase in the EITC (by moving earnings into the EITC eligible range). Given the two potential earners in the household, it is less likely that a shock would lead to movement out of the labor market entirely. This is consistent with the evidence in Table 2.

To more fully explore the differences by marital status and the connections to labor supply predictions, we estimate our models on the full sample of filers. In particular, we assign each filer to one of six earnings "regions": phase-in, flat, phase-out, "near" phase-out (the region $\$ 25,000$ above the end of the phase-out for families with children; $\$ 15,000$ above for the childless), above the "near" phase-out, and the remaining filers (negative or zero earned income). These regions are assigned

\footnotetext{
${ }^{19}$ The vertical axis has the same scale for each figure to aid the visual comparisons across groups. There are a few small states that are off the scale for married couples with children. The linear fit, however, uses all of the observations.
} 
using the appropriate tax schedule for that group and tax year (e.g. filing status, number of dependents). The observations are defined as in Table 2 - by state, year, filing status and number of children $(0,1,2$ or more). The weighted counts of filers are, as in Table 2 , divided by the CPS population of potential filers for the relevant demographic group. ${ }^{20}$ Note that we do not condition on EITC participation for this analysis as we are interested in how earnings adjusts in economic cycles. An important caveat to these results is that our sample is censored to include only those who file taxes. In particular, many families whose earnings drop to zero will not be required to file taxes.

These results, presented in Table 3, provide support for our labor supply interpretation. First, single persons with children exhibit pro-cyclical filing status - a one percentage point increase in the unemployment rate leads to a 1.7 percent reduction in filers per potential filer. Second, childless filers also show pro-cyclical status, with a 1.5 percent reduction per potential filer. As expected, in light of their two potential earner households, married couples show a very small and statistically insignificant relationship between cycles and filing. The results for single parents with children show that an increase in unemployment is associated with a reduction in the propensity to have earnings in the flat and phase-out regions of the credit and an increase in the propensity to be in the phase-in region. This is consistent with the movements discussed in Figure 2-that is, one-earner households with relatively low earnings may experience some reduction in earnings within the EITC schedule. However these estimates are not statistically significant. Single parents with children also exhibit a statistically significant reduction in the propensity to have earnings above the phase-out region. Married couples with children show a statistically significant increase in EITC eligibility (with an increase in the unemployment rate) and a decrease in propensity to have earned income above the phase-out region (with the results concentrated in the region above the near phase-out).

To put these results in context, it is useful to compare these results to estimates for the cyclicality of other key safety net programs. These results are presented in Table 4, where we

\footnotetext{
${ }^{20}$ Because we are analyzing the full set of tax filers (rather than EITC recipients) we do not restrict the childless population to be 25-64 (for the CPS population counts).
} 
compare results for the EITC to AFDC/TANF (column 3), Food Stamps (column 4) and UI (column 5). For each model, the data is at the state-year level covering 1996-2008 and we divide the caseload by the state population (as opposed to the state population of potential filers as before). For the EITC, we present two measures - all EITC participants (column 1) and EITC participants with children (column 2). The results in these first two columns show that a one percentage point increase in the unemployment rate leads to a 2.3 percent increase in the EITC caseload, and a somewhat smaller 1.8 percent increase for EITC participants with children. ${ }^{21}$ The net result is significantly less protection provided by the (aggregate) EITC in recessions than is provided by the other programs. The remaining columns show that a one percentage point increase in the unemployment rate leads to an increase in per capita caseloads of 8.4 percent for Food Stamps, 7.7 percent for TANF, and 14.5 percent for UI. Even the most "cyclical” EITC group, married families with children (for whom a one percentage point increase in the unemployment rate leads to a 6.3 percent increase in caseloads), exhibits less countercyclical movements than TANF, Food Stamps, and unemployment compensation.

As a second way to put these results in context, we use the March CPS to explore how the EITC affects the cyclicality of income and poverty. Using our "alternative" post-tax, post-transfer income measure, we assign whether a family has income below 50, 100, 150 and 200 percent of poverty. We then zero out the EITC from the income measure and recalculate poverty. This data is collapsed to cells based on state, year, marital status and presence of children (as with the SOI data). The results, estimating the same model as (1) above, are presented in Table 5. We present estimates stratified on our three main groups: childless, single with children, and married with children. The first four columns confirm existing research documenting a positive relationship between unemployment rates and poverty (Bitler and Hoynes 2010, 2013, Blank 1989, 1993, Blank and

\footnotetext{
${ }^{21}$ The results for the pooled EITC sample (column 1, table 4) differ slightly from the results for the pooled sample in table 2 (column 1). Here, in table 4, we wanted to use a consistent definition for the denominator across the columns in the table. Given the range of programs here, we opted to use the state total population as the denominator (rather than the number of potential filers that we used in Table 2). This shows minor sensitivity to the choice of denominators.
} 
Blinder 1986, Blank and Card 1993, Cutler and Katz 1991, Freeman 2001, Gunderson and Ziliak 2004, Hoynes et al. 2006, Meyer and Sullivan 2011). For example, a one percentage point increase in unemployment leads to a 1.2 percentage point, or 5.7 percent, increase in official poverty for single families with children (panel 2, column 2). The percent responses are larger for married families with children and smaller (and insignificant) for "extreme" poverty (below 50 percent). The results in the last four columns show that if we eliminate the EITC from family income, poverty becomes more cyclically sensitive. Consistent with the SOI analysis, the biggest differences (and hence the strongest protective element of the EITC) is among married couples with children. These differences are modest, however. For example, a one percentage point increase in the unemployment rate leads to a 9.7 percent increase in poverty (100\%) for married families with children, which increases to 10.5 percent without the EITC. It is important to remember that this is a static analysis; we eliminate the EITC and assume that nothing else in the household changes (that is, in the absence of an EITC, previous research suggests that not only would EITC payments go down for these married families, but hours might go up) $)^{22}$.

\section{Additional Results and Sensitivity Checks}

The validity of our estimates requires that the changes in state unemployment rates are not reflecting other policies or trends at the state level. We explore this in two ways, with the results presented in Table 6. First, we control for other state policies including welfare reform, indicators for the presence of state EITC programs, and state Medicaid/SCHIP income eligibility thresholds. The results show (base case in column 1, adding state-year controls in column 2) that the results are highly robust to these controls. Second, we include state-specific linear time trends (in column 3). Adding state linear trends changes the coefficients somewhat (leading to increases for single families with children and decreases for married couples with children), but the qualitative conclusions are

\footnotetext{
${ }^{22}$ Similarly, if the EITC were eliminated, poverty would likely increase by more for the single families than is suggested by the loss of their EITC benefits, as previous work suggests these families' labor supply is increased by the presence of the EITC.
} 
unchanged. Finally, we add both trends and controls, with the results close to those with state linear trends.

Because individuals can file federal tax returns for previous years, each tax-year crosssection of the SOI data contains not only returns for that tax year, but also for previous years. For example, in calendar year 2006, most individuals file returns for income earned and taxes due for 2005. However, a few individuals file for taxes due in 2004, 2003, etc. We refer to these individuals as late filers. In our data, we have information on the year when the return was physically filed, as well as the tax year for which the return is filed. Hence we are able to identify late filers, who represent around 2.8 percent of our weighted sample.

Because in our empirical analysis we are estimating the contemporaneous effect of local labor market conditions on the size of the EITC, keeping late filers in our sample could introduce measurement error (and attenuated results) or possibly introduce a systematic bias in the sample. While the ideal specification would require us to re-classify the year variable so that it refers to the year for which the federal returns were filed, and not the tax year in which they were filed, this reclassification cannot be done appropriately for the entire time period. In the last few years of data (2007 and 2008) not all late filers would have shown up. For this reason, in our main specification, we exclude from the sample all late filers. However, to explore the sensitivity to dropping late filers, we estimate models where we restrict the analysis to the years 1996-2004 (when we expect that most late filings for tax year 2004 have shown up). Table 7 presents the results obtained for three alternative treatments of late filers. In Panel A, we retain the late filers and do not alter the tax year variable (the late filers appear in the counts for the year when they filed the returns). In Panel B, we re-classify late filers to the tax year for which the federal returns were filed. In Panel C, we exclude all the late filers from the sample (our baseline specification but for 1996-2004). The results show that our results are not very sensitive to this construction the sample. The estimated effect of the state unemployment rate on the size of the EITC does not vary significantly in the three panels.

Our results end our sample period in 2008 because this is the last year for which the SOI 
micro data is available. This is unfortunate given that we miss the full extent of the Great Recession; the unemployment rate rose from 4.6 in 2007, to 5.8 in 2008, 9.3 in 2009, and 9.6 in 2010 before beginning to fall (to 8.9 in 2011 and 8.1 in 2012). We were able, though, to obtain summary data from the IRS on EITC participants, by state and filing status (single, head of household, married) for 2009-2010. We collapse our original SOI data to match the data available for 2009-2010 and use this to estimate more aggregated models using data through 2010. These three groups are a little different from the preferred demographic groups we use above. In particular, single corresponds to single no children, head of household corresponds to single with children, and married includes married with and without children. We present these results in Table 8. In panel A, we estimate the models for the (base) period 1996-2008. These results differ from Table 2 only in the aggregation to these three filing status groups. In panel B, we present estimates for same groups but with data extended through 2010. The results are virtually unchanged by the addition of these two years.

Our last sensitivity test relates to our use of the CPS to construct the potential filer population in the denominator of the caseload and expenditure measures. We explored several different definitions for the denominators in an effort to best capture the EITC filing rules (especially as they relate to dependents) within the available CPS data. These results, presented in Appendix Table 3, show very little difference across the alternative definitions for the at risk population. ${ }^{23}$

\section{Conclusion}

Welfare reform and the expansion of the EITC have dramatically changed the landscape of policies of redistribution for low income families with children in the United States. This change has

\footnotetext{
${ }^{23}$ The denominator, the population of potential filers, is constructed according to the marital status of the family head and the number of children in the family. The alternative definitions presented in Appendix Table 3 differ only on the methodology used to identify children in the family. In the first definition, we identify as children individuals that are 18 or younger. In the second one, we identify as children individuals 19 or younger, or individuals 24 or younger that are full time students. In the third case, we modify the second definition of children to include disabled individuals and to exclude non-citizens. Lastly, in our fourth alternative we identify children as in the second definition, include disabled and perform a "filers maximization" algorithm. This algorithm mimics tax noncompliance behavior when tax filers strategically declare dependent children in order to minimize the tax burden of the household.
} 
led to a movement away from "out of work" benefits, with their strong work disincentives, and an increase in "in work" benefits, which promote employment. This dramatic policy shift has been followed by other developed countries (Owens 2005).

The research shows that these policies have been successful at increasing the employment of single mothers with children (Eissa and Liebman 1996, Meyer and Rosenbaum 2000, 2001, Grogger 2003). Additionally, results based on the new Supplemental Poverty Measure, first released by the Census in 2011, show that the EITC is the most important anti-poverty program for families with children. The Census tabulations show that the EITC removes 4.7 million children from poverty, more than any other tax or transfer program (Short 2012).

In light of the importance of the EITC for lower income families, in this paper we evaluate whether the EITC satisfies a central tenet of safety net programs - that they provide protection in times of economic need. Additionally, the Great Recession provides our first opportunity to test our transformed safety net. We examine this issue by using administrative tax records to estimate the cyclicality of the EITC. We do so by leveraging substantial variation across states in the timing and severity of cycles which we measure with the state unemployment rate.

Our results show that for the largest group of EITC recipients, single mothers with children, there is a weak and statistically insignificant but negative relationship between unemployment rates and their use of the EITC. This implies that the EITC is pro-cyclical for this group - with EITC resources declining in recessions. It therefore does not provide an automatic-stabilizer or income protection for this group. On the other hand, for married couples with children (and to a lesser extent the childless), use of the EITC is found to rise in recessions. These results can be understood within the context of labor supply theory and in particular connect to the different predictions for how earnings changes for one- versus two-earner households.

To put these results in perspective, we compare the cyclicality of the EITC to other safety net programs finding that TANF, Food Stamps, and (unsurprisingly) UI are substantially more cyclical than the EITC. 


\section{References}

Baker, K. (2008). "Do Cash Transfer Programs Improve Infant Health: Evidence from the 1993 Expansion of the Earned Income Tax Credit," mimeo, University of Notre Dame.

Baughman, R. and Dickert-Conlin, S. (2009). “The Earned Income Tax Credit and Fertility," Journal of Population Economics, Vol. 22(3): 537-63.

Blank, R. (1989). "Disaggregating the Effect of the Business Cycle on the Distribution of Income," Economica, 56:141-163.

Blank, R. (1993), "Why were Poverty Rates so High in the 1980s?" In Poverty and Prosperity in the Late Twentieth Century. Papadimitriou and Wolff, eds, St Martin’s Press.

Blank, R. (2001). "What Causes Public Assistance Caseloads to Grow?", Journal of Human Resources, Vol. 36(1): 85-118.

Blank, R. and A. Blinder (1986). "Macroeconomics, Income Distribution, and Poverty" In Fighting Poverty: What Works and What Doesn’t. Danziger and Weinberg, eds. Harvard University Press.

Blank, R. and D. Card (1993), "Poverty, Income Distribution and Growth: Are They Still Related?" Brookings Papers on Economic Activity 2:1993.

Bitler, M. and H. Hoynes (2010)."The State of the Safety Net in the Post-Welfare Reform Era", Brookings Papers on Economic Activity: 71-127.

Bitler, M. and H. Hoynes (2013). "Immigrants, Welfare and the U.S. Safety Net" in David Card and Steven Raphael (eds), Immigration, Poverty, and Socioeconomic Inequality, in press, Russell Sage Foundation, New York, NY.

Chetty, R., Friedman, J., and Saez, E. (2013). "Using Differences in Knowledge Across Neighborhoods to Uncover the Impact of the EITC on Earnings," American Economic Review, forthcoming.

Corsetto, L. (2012). "Food and Nutrition Program Cyclicality,” mimeo, UC Davis.

Cutler and Katz 1991,"Macroeconomic Performance and the Disadvantaged", Brookings Papers on Economic Activity 1:1994.

Dahl, G. and Lochner, L. (2012). "The Impact of Family Income on Child Achievement: Evidence from the Earned Income Tax Credit," American Economic Review: Vol. 102(5): 1927-56.

Dalaker, Joe 2005. Alternative Poverty Estimates in the United States, Current Population Report P60-227, United States Bureau of the Census.

Dehejia, R. and A. Lleras-Muney (2004). "Booms, Busts, and Babies' Health.” Quarterly Journal of Economics, Vol. 119, No. 3, pp. 1091-1130.

Dickert-Conlin, S. (2002). “EITC and Marriage,” National Tax Journal, Vol. 55(1): 25-40. 
Eissa, N. and Hoynes, H. (2004). "Taxes and the Labor Market Participation of Married Couples:

The Earned Income Tax Credit," Journal of Public Economics, Vol. 88 (9-10): 1931-58.

Eissa, N. and Hoynes, H. (2006). "Behavioral Responses to Taxes: Lessons from the EITC and Labor Supply," Tax Policy and the Economy, Vol. 20: 74-110.

Eissa, N. and Liebman, J. (1996). "Labor Supply Response to the Earned Income Tax Credit," Quarterly Journal of Economics, Vol. 111: 605-37.

Ellwood, D. (2000). "The Impact of the Earned Income Tax Credit and Social Policy Reforms on Work, Marriage and Living Arrangements," National Tax Journal, Vol. 53(4).

Evans, W. and Garthwaite, C. (2010). "Giving Mom a Break: The Impact of Higher EITC Payments on Maternal Health,” NBER Working Paper 16296.

Freeman, R. (2001). “The Rising Tide Lifts...?” In Sheldon Danziger and Robert Haveman, eds., Understanding Poverty, Cambridge, MA: Harvard University Press, 97-126.

Grogger, J. (2003), "The Effects of Time Limits, the EITC, and Other Policy Changes on Welfare Use, Work, and Income Among Female-Headed Families." Review of Economics and Statistics 85(2):394-408.

Gundersen, Craig and James Ziliak. 2004. "Poverty and Macroeconomic Performance across Space, Race, and Family Structure,” Demography, 41:1, 61-86.

Herbst, C. (2011). "The Impact of the Earned Income Tax Credit on Marriage and Divorce: Evidence from Flow Data," Population Research and Policy Review, Vol. 30: 101--28.

Hotz, J. and Scholz, K. (2003). "The Earned Income Tax Credit," in Means-Tested Transfer Programs in the United States.

Hoynes, Hilary W., Douglas L. Miller, and David Simon. 2012. Income, the Earned Income Tax Credit, and Infant Health. NBER Working Paper 18206

Hoynes, Hilary W., Marianne E. Page, and Ann Huff Stevens. 2006. "Poverty in America: Trends and Explanations." Journal of Economic Perspectives 20: 47-68.

Internal Revenue Service (2011). EITC Statistics, Report NR. 701-98-11 December 2011. http://www.eitc.gov.irs.gov/central/eitcstats/

Meyer, B. and D. Rosenbaum (2001), "Welfare, the Earned Income Tax Credit, and the Labor Supply of Single Mothers", QJE 116(3): 1063-1114.

Meyer, B. and Rosenbaum, D. (2000). “A Making Single Mothers Work: Recent Tax and Welfare Policy and its Effects," National Tax Journal, Vol. 53: 1027-1062.

Meyer, B. and D. Sullivan (2011). "Consumption and Income Poverty over the Business Cycle," Research in Labor Economics, vol. 32, 51-82.

Owens, J. (2005). "Fundamental Tax Reform: The Experience of OECD Countries," Background Paper, Number 47, Tax Foundation. 
Saez, E. (2010). “Do Taxpayers Bunch at Kink Points?” American Economic Journal: Economic Policy 2(3), 2010, 180-212.

Schaller, J. (2012) "For richer if not for poorer? Marriage and divorce over the business cycle," Journal of Population Economics.

Schaller, J. (2013) "Booms, busts, and fertility: testing the Becker model using gender-specific labor demand," working paper, University of Arizona.

Short, K. (2011). "The Research Supplemental Poverty Measure: 2010.” Current Population Reports P60-241. U.S. Census Bureau.

Short, K. (2012). "The Research Supplemental Poverty Measure: 2011.” Current Population Reports P60-244. U.S. Census Bureau.

U.S. Department of Agriculture 2013. Caseload Data. Unpublished data provided by Katie Fitzpatrick and

John Kirlin of the Economic Research Service.

U.S. Department of Health and Human Services Administration for Children and Families, 2013.

Caseload Data. [online] Office of Family Assistance. Available at:

http://www.acf.hhs.gov/programs/ofa/data-reports/index.htm.

U.S. Department of Labor 2013. 1979-2010 Data. Unpublished data provided by DOL OSEC.

Ziliak, J. P., Figlio, D. N., Davis, E. E., and Connolly, L. S. (2000). “Accounting for the Decline in AFDC Caseloads: Welfare Reform or the Economy?" Journal of Human Resources, Vol. 35(3): 57086.

Ziliak, J. P., Gundersen, C. and Figlio, D. N. et al. (2003). "Food stamp caseloads over the business cycle,” Southern Economic Journal, Vol. 69 (4): 903-19. 
Table 1: Summary Statistics, EITC Filers and Expenditures, 2008

\begin{tabular}{lc}
\hline \hline & \\
Total EITC Participants (Millions) & 24.4 \\
Total EITC Expenditures (Billions 2008\$) & $\$ 50.5$ \\
& \\
& \\
Percent Distribution of Caseload, by demographic group & \\
\hline Childless & $21.9 \%$ \\
Single with Children & $58.7 \%$ \\
Married with Children & $19.4 \%$ \\
& \\
Percent Distribution of Expenditures, by demographic group & \\
\hline Childless & $2.7 \%$ \\
Single with Children & $74.1 \%$ \\
Married with Children & $23.2 \%$ \\
& \\
Average Credit Amount (2008\$), by demographic group & \\
\hline Childless & $\$ 253$ \\
Single with Children & $\$ 2,613$ \\
Married with Children & $\$ 2,471$ \\
\end{tabular}

Notes: Data are from the 2008 Statistics of Income, which contains information on tax returns for tax year 2008. The sample excludes high-income earners, individuals living abroad, late filers and married couples filing separately. Statistics are weighted to represent population of tax filers.

Table 2: Effects of Unemployment Rate on EITC Caseloads and Expenditures

\begin{tabular}{lcccc}
\hline \hline & $(1)$ & $(2)$ & $(3)$ & $(4)$ \\
& All & No Kids & Kids, Single & Kids, Married \\
\hline \hline A: EITC Caseloads & & & & \\
Unemployment Rate & $0.004^{*}$ & $0.003^{*}$ & -0.009 & $0.009^{* * *}$ \\
& $(0.002)$ & $(0.001)$ & $(0.013)$ & $(0.003)$ \\
\hline Mean Y & 0.220 & 0.079 & 0.855 & 0.144 \\
Percent Impact (\%) & 1.8 & 3.2 & -1.0 & 6.3 \\
Observations & 663 & 1326 & 1326 & 1326 \\
& & & & \\
\hline B: EITC Dollars & & & & \\
Unemployment Rate & 5.6 & 0.5 & -23.1 & $20.5^{* * *}$ \\
& $(6.1)$ & $(0.5)$ & $(38.6)$ & $(6.7)$ \\
\hline Mean Y & 460.5 & 20.1 & 2201.6 & 345.3 \\
Percent Impact (\%) & 1.2 & 2.3 & -1.0 & 5.9 \\
Observations & 663 & 1326 & 1326 & 1326 \\
\hline \hline
\end{tabular}

Notes: Data are from the 1996-2008 Statistics of Income, with denominators measuring the number of potential tax filers from the CPS ASEC. The sample excludes high-income earners, late filers, individuals living abroad and married couples filing separately. The dependent variables are total EITC caseloads and real EITC expenditures $(\$ 2008)$, both divided by the total population of potential filers in each cell. All regressions include controls for demographic characteristics, as well as state and year fixed effects. The results are weighted by the population of potential filers in each cell. Standard errors are clustered by state and shown in parentheses. ${ }^{*} \mathrm{p}<0.10,{ }^{* *} \mathrm{p}<0.05$, $* * * \mathrm{p}<0.01$. 
Table 3: Effect of Unemployment Rate on EITC Eligibility According to Earned Income

\begin{tabular}{|c|c|c|c|}
\hline & $\begin{array}{c}(1) \\
\text { No Kids }\end{array}$ & $\begin{array}{c}(2) \\
\text { Kids, Single }\end{array}$ & $\begin{array}{c}(3) \\
\text { Kids, Married }\end{array}$ \\
\hline \multicolumn{4}{|l|}{ Total Filers } \\
\hline Unemployment Rate & $\begin{array}{c}-0.015^{* *} \\
(0.006)\end{array}$ & $\begin{array}{l}-0.019^{*} \\
(0.010)\end{array}$ & $\begin{array}{c}0.002 \\
(0.006)\end{array}$ \\
\hline Share of Filers & 1.00 & 1.00 & 1.00 \\
\hline Mean Y & 1.021 & 1.135 & 0.818 \\
\hline Percent Impact (\%) & -1.5 & -1.7 & 0.3 \\
\hline Observations & 1326 & 1323 & 1326 \\
\hline \multicolumn{4}{|c|}{ Filers in the eligible region } \\
\hline Unemployment Rate & $\begin{array}{l}-0.002 \\
(0.002)\end{array}$ & $\begin{array}{l}-0.006 \\
(0.010)\end{array}$ & $\begin{array}{c}0.011^{* * *} \\
(0.003)\end{array}$ \\
\hline Share of Filers & 0.25 & 0.74 & 0.24 \\
\hline Mean Y & 0.273 & 0.839 & 0.192 \\
\hline Percent Impact (\%) & -0.7 & -0.7 & 5.5 \\
\hline Observations & 1326 & 1323 & 1326 \\
\hline \multicolumn{4}{|c|}{ Filers in the phase-in region } \\
\hline Unemployment Rate & $\begin{array}{l}-0.001 \\
(0.001)\end{array}$ & $\begin{array}{c}0.002 \\
(0.005)\end{array}$ & $\begin{array}{l}0.003^{* *} \\
(0.001)\end{array}$ \\
\hline Share of Filers & 0.13 & 0.18 & 0.03 \\
\hline Mean Y & 0.141 & 0.195 & 0.026 \\
\hline Percent Impact (\%) & -0.5 & 0.8 & 11.1 \\
\hline Observations & 1326 & 1323 & 1326 \\
\hline \multicolumn{4}{|l|}{ Filers in the flat region } \\
\hline Unemployment Rate & $\begin{array}{l}-0.000 \\
(0.001)\end{array}$ & $\begin{array}{l}-0.002 \\
(0.004)\end{array}$ & $\begin{array}{c}0.001 \\
(0.001)\end{array}$ \\
\hline Share of Filers & 0.03 & 0.15 & 0.04 \\
\hline Mean Y & 0.033 & 0.175 & 0.030 \\
\hline Percent Impact (\%) & -1.0 & -1.1 & 2.8 \\
\hline Observations & 1326 & 1323 & 1326 \\
\hline \multicolumn{4}{|c|}{ Filers in the phase-out region } \\
\hline Unemployment Rate & $\begin{array}{l}-0.001 \\
(0.001)\end{array}$ & $\begin{array}{l}-0.006 \\
(0.006)\end{array}$ & $\begin{array}{l}0.006^{* *} \\
(0.003)\end{array}$ \\
\hline Share of Filers & 0.09 & 0.41 & 0.17 \\
\hline Mean Y & 0.101 & 0.469 & 0.142 \\
\hline Percent Impact (\%) & -0.7 & -1.2 & 4.3 \\
\hline Observations & 1326 & 1323 & 1326 \\
\hline \multicolumn{4}{|c|}{ Filers in the "near" phase-out region } \\
\hline Unemployment Rate & $\begin{array}{l}-0.005^{*} \\
(0.003)\end{array}$ & $\begin{array}{c}-0.007^{* *} \\
(0.004)\end{array}$ & $\begin{array}{c}0.002 \\
(0.003)\end{array}$ \\
\hline Share of Filers & 0.18 & 0.17 & 0.24 \\
\hline Mean Y & 0.192 & 0.192 & 0.197 \\
\hline Percent Impact (\%) & -2.8 & -3.8 & 1.1 \\
\hline Observations & 1326 & 1323 & 1326 \\
\hline \multicolumn{4}{|c|}{ Filers above the "near" phase-out region } \\
\hline Unemployment Rate & $\begin{array}{c}-0.011^{* * *} \\
(0.003)\end{array}$ & $\begin{array}{c}-0.006^{* * *} \\
(0.002)\end{array}$ & $\begin{array}{c}-0.011^{* *} \\
(0.005)\end{array}$ \\
\hline Share of Filers & 0.41 & 0.07 & 0.52 \\
\hline Mean Y & 0.393 & 0.085 & 0.424 \\
\hline Percent Impact (\%) & -2.9 & -7.4 & -2.5 \\
\hline Observations & 1326 & 1323 & 1326 \\
\hline \multicolumn{4}{|c|}{ Filers with Negative or Zero Earned Income } \\
\hline$\overline{\text { Unemployment Rate }}$ & $\begin{array}{c}0.004^{*} \\
(0.002)\end{array}$ & $\begin{array}{c}0.001 \\
(0.001)\end{array}$ & $\begin{array}{c}0.000 \\
(0.000)\end{array}$ \\
\hline Share of Filers & 0.17 & 0.02 & 0.01 \\
\hline Mean Y & 0.166 & 0.020 & 0.012 \\
\hline Percent Impact (\%) & 2.1 & 3.3 & 1.9 \\
\hline Observations & 1326 & 1323 & 1326 \\
\hline
\end{tabular}

Notes: Data are from the 1996-2008 Statistics of Income, with denominators measuring the number of potential tax filers from the CPS ASEC. The sample excludes high-income earners, individuals living abroad, late filers and married couples filing separately. Each panel regression is the number of filers whose earned income puts them in the EITC eligible range (or slightly above or at zero/negative income) divided by the population 
Table 4: Effect of Unemployment Rate on Other Safety Net Programs

\begin{tabular}{lccccc}
\hline \hline & $(1)$ & $(2)$ & $(3)$ & $(4)$ & $(5)$ \\
& EITC & EITC & & & \\
& All & With Kids & AFDC/TANF & Food Stamps & UI \\
\hline State unemployment rate (CPS) - Annual & $0.002^{* *}$ & $0.001^{*}$ & $0.001^{*}$ & $0.003^{* * *}$ & $0.001^{* * *}$ \\
& $(0.001)$ & $(0.001)$ & $(0.000)$ & $(0.001)$ & $(0.000)$ \\
\hline Mean Y & 0.072 & 0.058 & 0.009 & 0.034 & 0.009 \\
Percent Impact (\%) & 2.3 & 1.8 & 7.7 & 8.4 & 14.5 \\
Observations & 663 & 663 & 663 & 663 & 663 \\
\hline \hline
\end{tabular}

Notes: Years 1996-2008. The dependent variables are EITC, AFDC/TANF, food stamps, and UI caseloads divided by the state population. Sources for caseloads are in text. All regressions include state and year fixed effects. The results are weighted by the state population. Standard errors are clustered by state and shown in parentheses. ${ }^{*} \mathrm{p}<0.10,{ }^{* *} \mathrm{p}<0.05$, $* * * \mathrm{p}<0.01$.

Table 5: Effect of Unemployment Rate on Poverty Rate: With and Without EITC

\begin{tabular}{|c|c|c|c|c|c|c|c|c|}
\hline & \multicolumn{4}{|c|}{ Alternative Poverty } & \multicolumn{4}{|c|}{ Subtract EITC } \\
\hline & $50 \%$ & $100 \%$ & $150 \%$ & $200 \%$ & $50 \%$ & $100 \%$ & $150 \%$ & $200 \%$ \\
\hline \multicolumn{9}{|l|}{ A: Childless } \\
\hline \multirow[t]{2}{*}{$\overline{\text { Unemployment Rate }}$} & $0.002^{* *}$ & $0.006^{* * *}$ & $0.009^{* * *}$ & $0.010^{* * *}$ & $0.002^{* *}$ & $0.006^{* * *}$ & $0.009^{* * *}$ & $0.010^{* * *}$ \\
\hline & $(0.001)$ & $(0.001)$ & $(0.002)$ & $(0.002)$ & $(0.001)$ & $(0.001)$ & $(0.002)$ & $(0.002)$ \\
\hline Mean Y & 0.048 & 0.099 & 0.174 & 0.256 & 0.049 & 0.100 & 0.174 & 0.256 \\
\hline Percent Impact (\%) & 4.4 & 5.5 & 5.0 & 3.9 & 4.3 & 5.7 & 5.0 & 3.9 \\
\hline Observations & 1326 & 1326 & 1326 & 1326 & 1326 & 1326 & 1326 & 1326 \\
\hline \multicolumn{9}{|l|}{ B: Single with Children } \\
\hline \multirow[t]{2}{*}{ Unemployment Rate } & 0.002 & $0.012^{* * *}$ & $0.019^{* * *}$ & $0.019^{* * *}$ & 0.001 & $0.015^{* * *}$ & $0.019^{* * *}$ & $0.018^{* * *}$ \\
\hline & $(0.002)$ & $(0.003)$ & $(0.003)$ & $(0.003)$ & $(0.002)$ & $(0.003)$ & $(0.003)$ & $(0.003)$ \\
\hline Mean Y & 0.072 & 0.209 & 0.351 & 0.511 & 0.081 & 0.244 & 0.391 & 0.537 \\
\hline Percent Impact (\%) & 2.3 & 5.7 & 5.5 & 3.7 & 1.9 & 6.3 & 4.7 & 3.3 \\
\hline Observations & 1326 & 1326 & 1326 & 1326 & 1326 & 1326 & 1326 & 1326 \\
\hline \multicolumn{9}{|l|}{ C: Married with Children } \\
\hline \multirow[t]{2}{*}{ Unemployment Rate } & 0.001 & $0.004^{* * *}$ & $0.008^{* * *}$ & $0.011^{* * *}$ & $0.001^{* *}$ & $0.006^{* * *}$ & $0.008^{* * *}$ & $0.011^{* * *}$ \\
\hline & $(0.000)$ & $(0.001)$ & $(0.002)$ & $(0.002)$ & $(0.000)$ & $(0.001)$ & $(0.002)$ & $(0.002)$ \\
\hline Mean Y & 0.013 & 0.043 & 0.104 & 0.200 & 0.016 & 0.054 & 0.115 & 0.205 \\
\hline Percent Impact (\%) & 6.0 & 9.7 & 7.9 & 5.6 & 7.6 & 10.5 & 7.2 & 5.3 \\
\hline Observations & 1326 & 1326 & 1326 & 1326 & 1326 & 1326 & 1326 & 1326 \\
\hline
\end{tabular}

Notes: Data from the CPS ASEC calendar years 1996-2008 and collapsed at the demographic group, state and year level. Children are defined following the definition for dependent children (same as children for EITC purposes). All regressions include controls for demographic characteristics, as well as state and year fixed effects. The results are weighted by the number of families in each cell. Standard errors are clustered by state and shown in parentheses. ${ }^{*} \mathrm{p}<0.10,{ }^{* *} \mathrm{p}<0.05,{ }^{* * *}$ $\mathrm{p}<0.01$. 
Table 6: Effect of Unemployment Rate on EITC Caseloads: Sensitivity to Adding State-Year Controls

\begin{tabular}{lcccc}
\hline \hline & \multicolumn{5}{c}{ EITC Caseloads } \\
\cline { 2 - 5 } & $(1)$ & $(2)$ & $(3)$ & $(4)$ \\
\hline \hline A: Caseload, childless & & & & \\
\hline Unemployment Rate & $0.003^{*}$ & $0.003^{*}$ & 0.002 & 0.001 \\
& $(0.001)$ & $(0.001)$ & $(0.002)$ & $(0.002)$ \\
\hline Observations & 1326 & 1326 & 1326 & 1326 \\
& & & & \\
\hline B: Caseload, single with children & & & \\
\hline Unemployment Rate & -0.009 & -0.008 & -0.015 & -0.017 \\
& $(0.013)$ & $(0.013)$ & $(0.016)$ & $(0.016)$ \\
\hline Observations & 1326 & 1326 & 1326 & 1326 \\
& & & & \\
\hline C: Caseload, married with children & & & \\
\hline Unemployment Rate & $0.009^{* * *}$ & $0.009^{* * *}$ & $0.005^{*}$ & $0.005^{*}$ \\
& $(0.003)$ & $(0.003)$ & $(0.003)$ & $(0.003)$ \\
\hline Observations & 1326 & 1326 & 1326 & 1326 \\
State Policies & & & & \\
State Linear Trend & & Yes & Yes & Yes \\
\hline \hline
\end{tabular}

Notes: Data are from the 1996-2008 Statistics of Income, with denominators measuring the number of potential tax filers from the CPS ASEC. The sample excludes high-income earners, individuals living abroad, late filers and married couples filing separately. The dependent variables are total EITC caseloads and real EITC expenditures (\$2008), both divided by the total population of potential filers in each cell. All regressions include controls for demographic characteristics, as well as state and year fixed effects. The results are weighted by the population of potential filers in each cell. Standard errors are clustered by state and shown in parentheses. ${ }^{*} \mathrm{p}<0.10,{ }^{* *} \mathrm{p}<0.05,{ }^{* * *} \mathrm{p}<0.01$. 
Table 7: Effects of the Unemployment Rate on EITC Caseloads: Sensitivity to Treatment of Late Filers

\begin{tabular}{|c|c|c|c|}
\hline & \multicolumn{3}{|c|}{ EITC Caseloads } \\
\hline & $\begin{array}{c}(1) \\
\text { No Kids }\end{array}$ & $\begin{array}{c}(2) \\
\text { Kids, Single }\end{array}$ & $\begin{array}{c}(3) \\
\text { Kids, Married }\end{array}$ \\
\hline \multicolumn{4}{|c|}{ A: By filing year, late filers included } \\
\hline Unemployment Rate & $\begin{array}{l}0.004^{* *} \\
(0.002) \\
\end{array}$ & $\begin{array}{l}-0.012 \\
(0.018)\end{array}$ & $\begin{array}{c}0.011^{* * *} \\
(0.003) \\
\end{array}$ \\
\hline Mean Y & 0.052 & 0.577 & 0.101 \\
\hline Percent Impact (\%) & 8.6 & -2.1 & 11.4 \\
\hline Observations & 1326 & 1326 & 1326 \\
\hline \multicolumn{4}{|c|}{ B: By tax year, late filers included } \\
\hline Unemployment Rate & $\begin{array}{c}0.005^{* * *} \\
(0.002)\end{array}$ & $\begin{array}{l}-0.013 \\
(0.018)\end{array}$ & $\begin{array}{c}0.011^{* * *} \\
(0.004)\end{array}$ \\
\hline Mean Y & 0.052 & 0.576 & 0.101 \\
\hline Percent Impact (\%) & 9.3 & -2.2 & 11.0 \\
\hline Observations & 1326 & 1326 & 1326 \\
\hline \multicolumn{4}{|c|}{ C: By tax year, late filers excluded [Basecase] } \\
\hline Unemployment Rate & $\begin{array}{l}0.004^{* *} \\
(0.002)\end{array}$ & $\begin{array}{l}-0.014 \\
(0.018)\end{array}$ & $\begin{array}{c}0.011^{* * *} \\
(0.003)\end{array}$ \\
\hline Mean Y & 0.049 & 0.564 & 0.098 \\
\hline Percent Impact (\%) & 8.1 & -2.4 & 11.5 \\
\hline Observations & 1326 & 1326 & 1326 \\
\hline
\end{tabular}

Notes: Data are from the 1996-2004 Statistics of Income, with denominators measuring the number of potential tax filers from the CPS ASEC. The sample excludes high-income earners, individuals living abroad and married couples filing separately. The dependent variable is total EITC caseloads divided by the total population of potential filers in each cell. All regressions include controls for demographic characteristics, as well as state and year fixed effects. The results are weighted by the population of potential filers in each cell. Standard errors are clustered by state and shown in parentheses. ${ }^{*} \mathrm{p}<0.10,{ }^{* *} \mathrm{p}<0.05,{ }^{* * *} \mathrm{p}<0.01$. 
Table 8: Effects of Unemployment Rate on EITC Caseloads: Sensitivity to Extending Sample to 2010

\begin{tabular}{lccc}
\hline \hline & \multicolumn{3}{c}{ EITC Caseloads } \\
\cline { 2 - 4 } & $\begin{array}{c}(1) \\
\text { Single }\end{array}$ & $\begin{array}{c}(2) \\
\text { Head of Household }\end{array}$ & $\begin{array}{c}(3) \\
\text { Married }\end{array}$ \\
\hline \hline A: Years 1996-2008 & & & \\
Unemployment Rate & -0.000 & 0.002 & $0.005^{* * *}$ \\
& $(0.003)$ & $(0.012)$ & $(0.002)$ \\
\hline Mean Y & 0.151 & 0.781 & 0.097 \\
Percent Impact (\%) & -0.3 & 0.3 & 5.3 \\
Observations & 663 & 663 & 663 \\
& & & \\
\hline B: Years 1996-2010 & & & \\
Unemployment Rate & 0.001 & -0.005 & $0.005^{* * *}$ \\
& $(0.002)$ & $(0.009)$ & $(0.001)$ \\
\hline Mean Y & 0.154 & 0.781 & 0.099 \\
Percent Impact (\%) & 0.5 & -0.6 & 4.8 \\
Observations & 714 & 714 & 714 \\
\hline \hline
\end{tabular}

Notes: Data are from the 1996-2008 Statistics of Income, with denominators measuring the number of potential tax filers from the CPS ASEC. The sample excludes high-income earners, individuals living abroad, late filers and married couples filing separately. The dependent variables are total EITC caseloads and real EITC expenditures (\$2008), both divided by the total population of potential filers in each cell. All regressions include controls for state and year fixed effects. The results are weighted by the population of potential filers in each cell. Standard errors are clustered by state and shown in parentheses. * $\mathrm{p}<0.10,{ }^{* *} \mathrm{p}<0.05,{ }^{* * *} \mathrm{p}<0.01$. 
Figure 1: Per Capita Expenditures on Cash and Near Cash Transfer Programs for Families (2009\$)

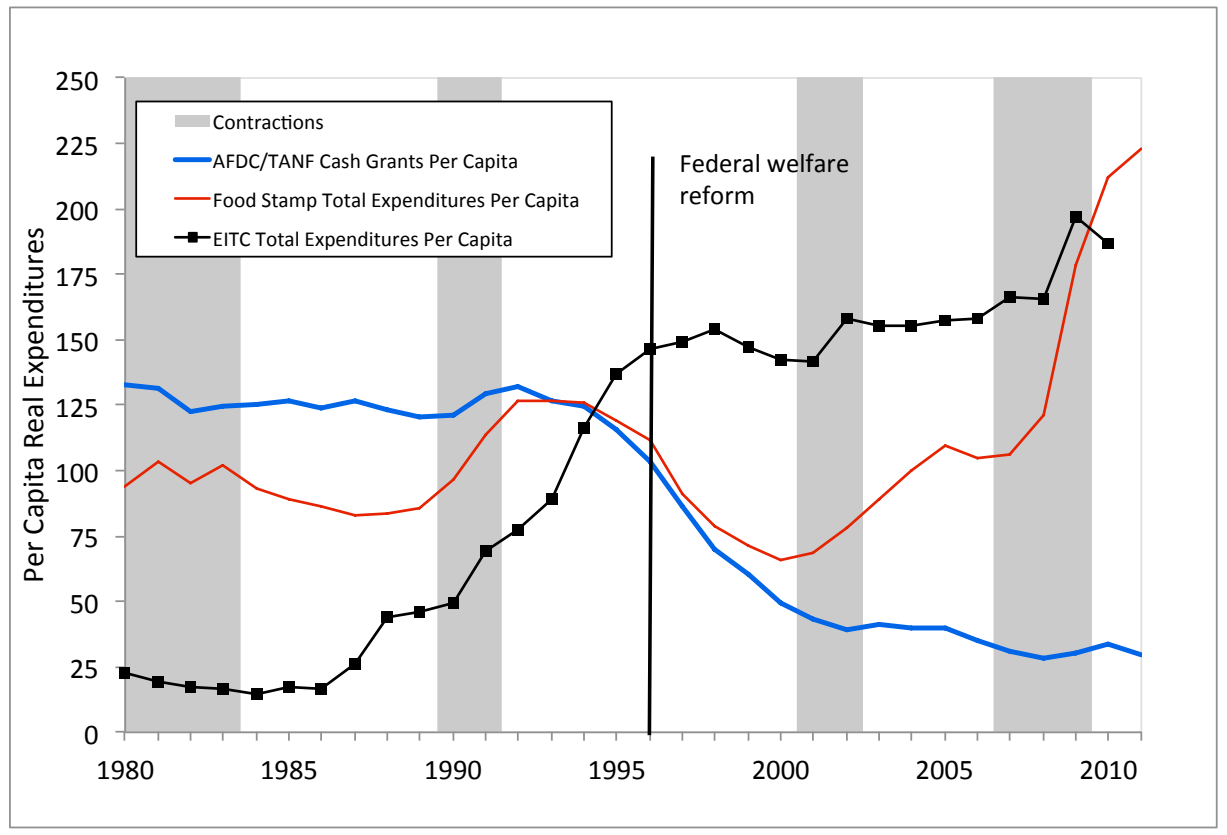

Sources: Bitler and Hoynes (2010) and updated data.

Figure 2: EITC Schedule for Single Parent with Two Children (2012), and Predicted Effects

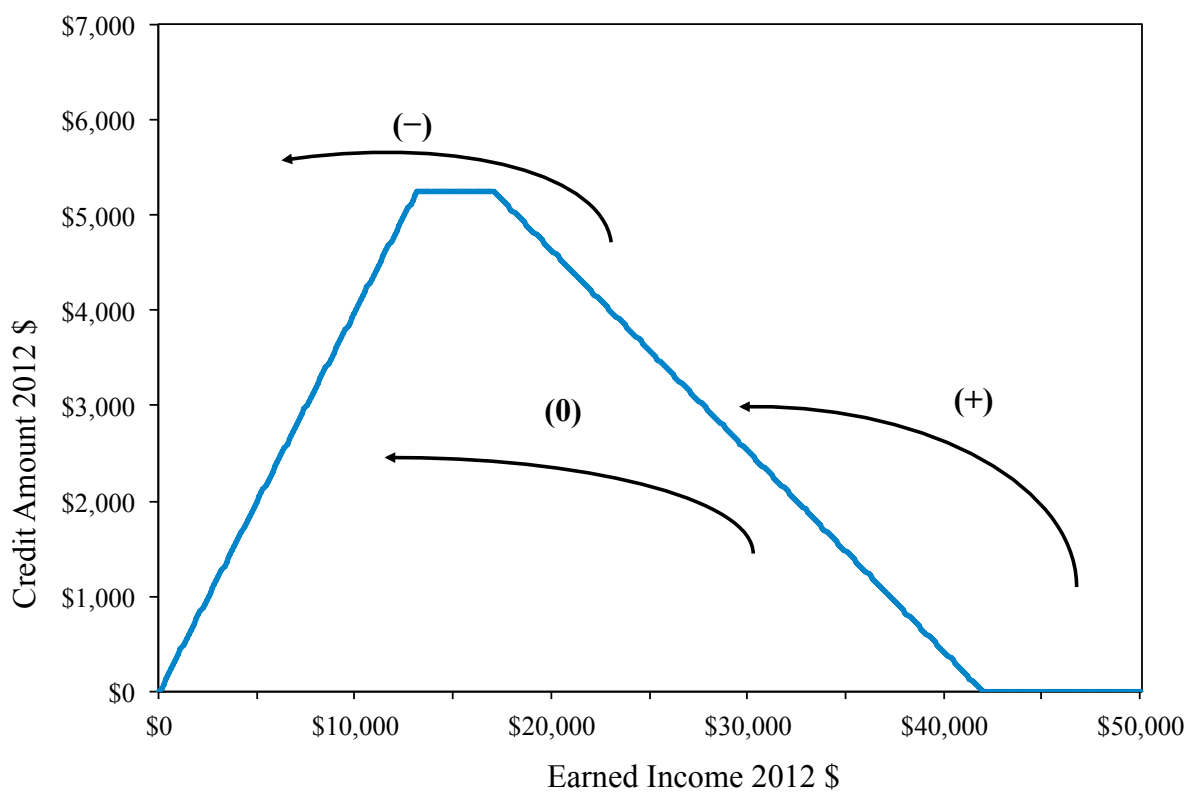


Figure 3: EITC Maximum Benefits By Number of Children (2012\$)

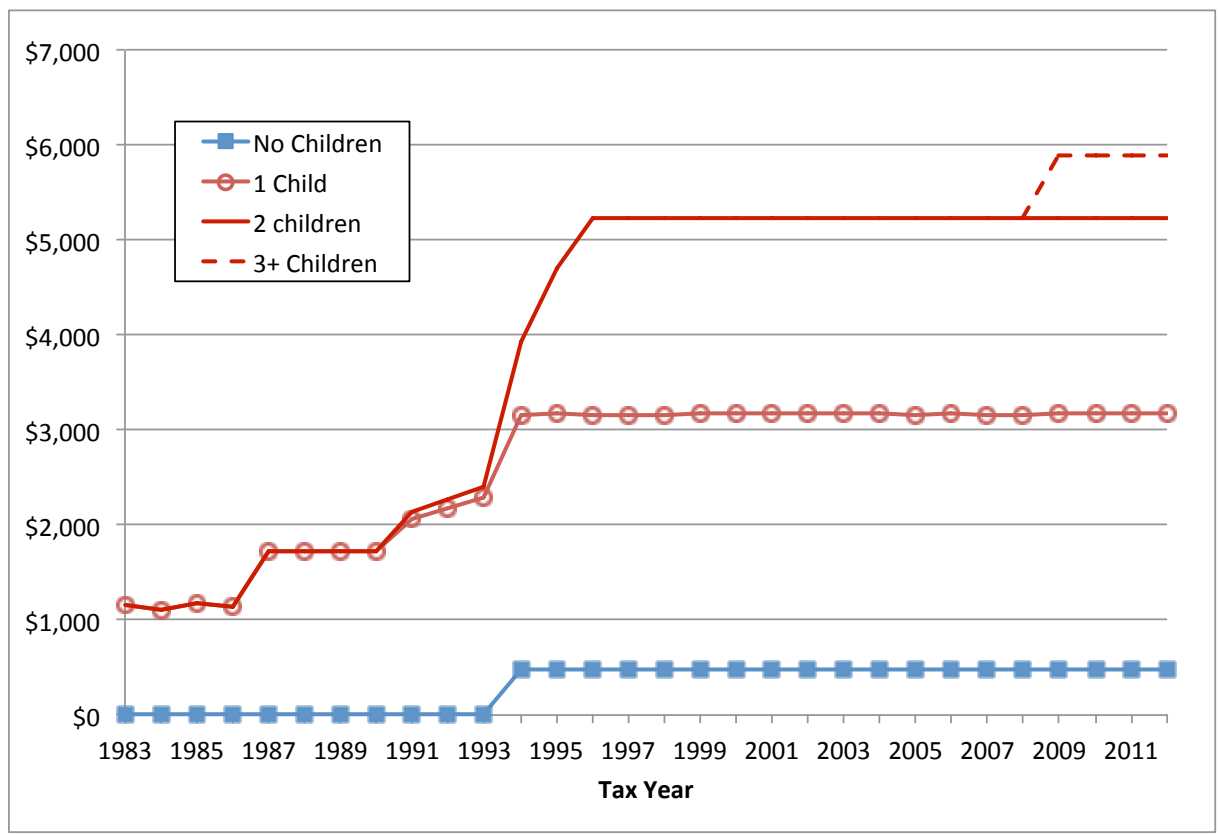

Sources: Data on nominal EITC benefits are from Tax Policy Center. Data on CPI are from the BLS. 
Figure 4: EITC Eligibility and Earned Income Distribution - 2006

(a) Single, No Children

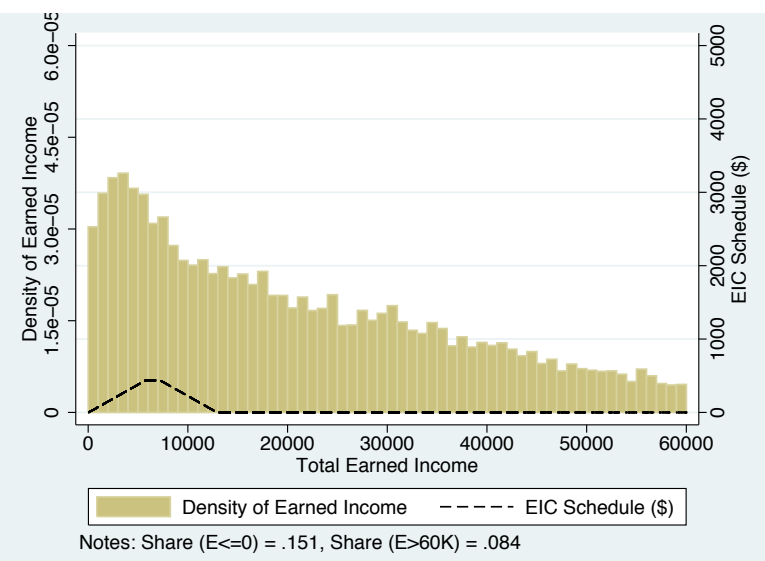

(c) Single, One Child



(e) Single, Two+ Children

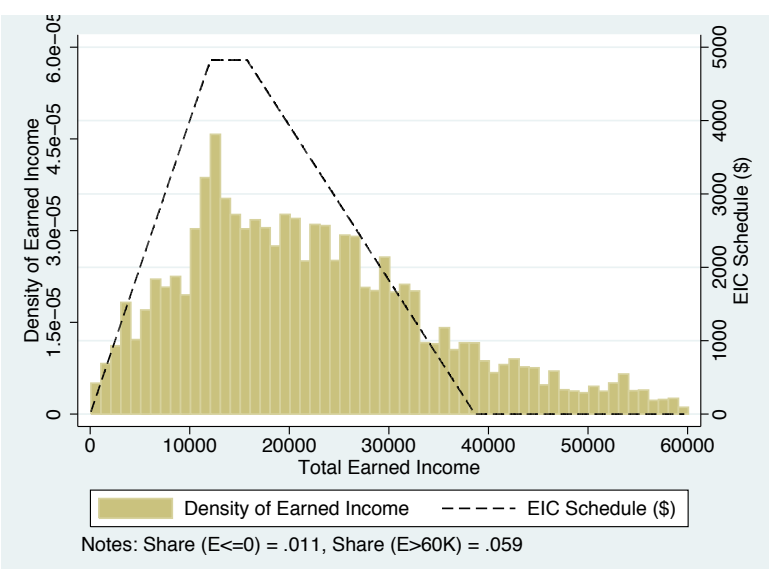

(b) Married, No Children

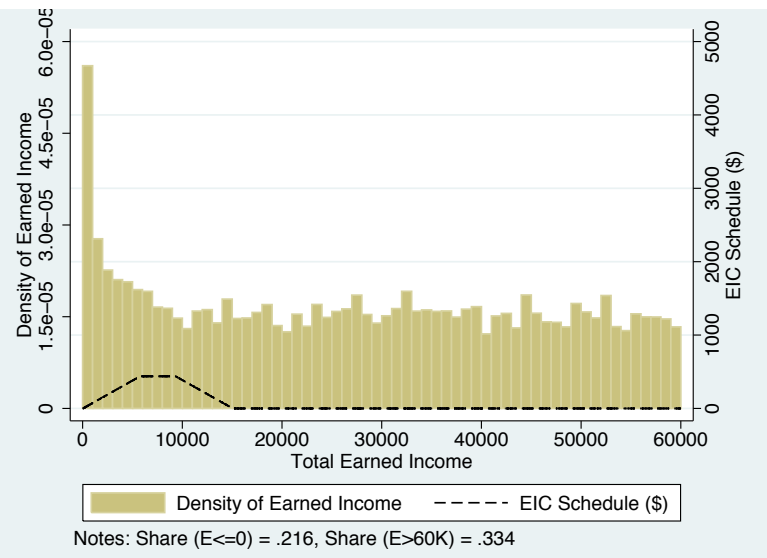

(d) Married, One Child

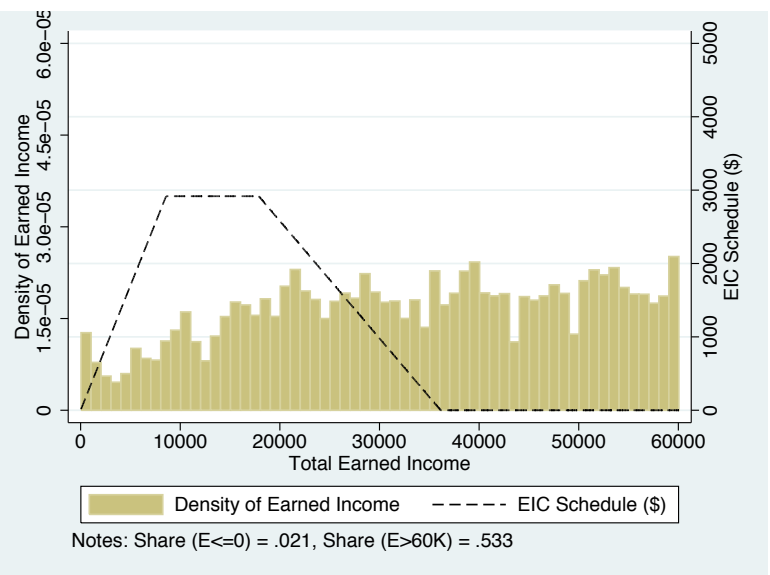

(f) Married, Two+ Children

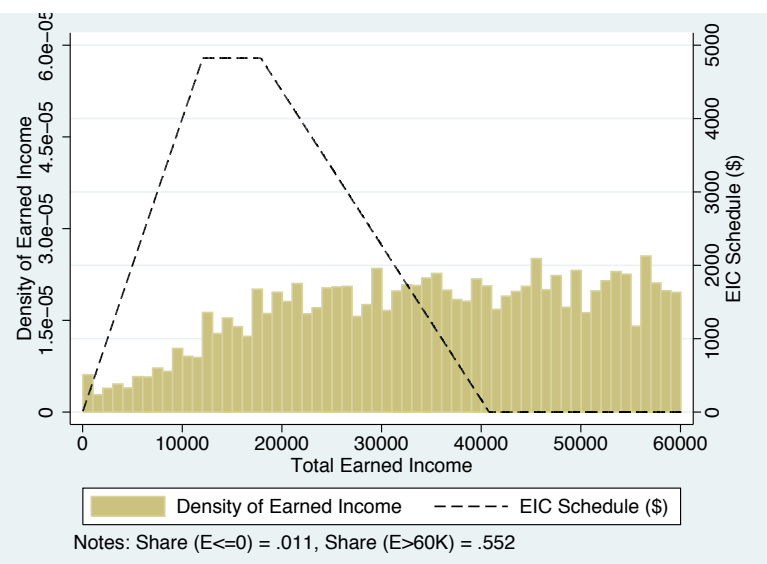

Notes: Data from Statistics of Income for tax year 2006. The sample excludes high-income earners, individuals living abroad, late filers and married couples filing separately. Histograms are weighted to represent population of tax filers. 
Figure 5: EITC Caseloads and Unemployment Rates (2000-2008 Changes), By State

(a) All

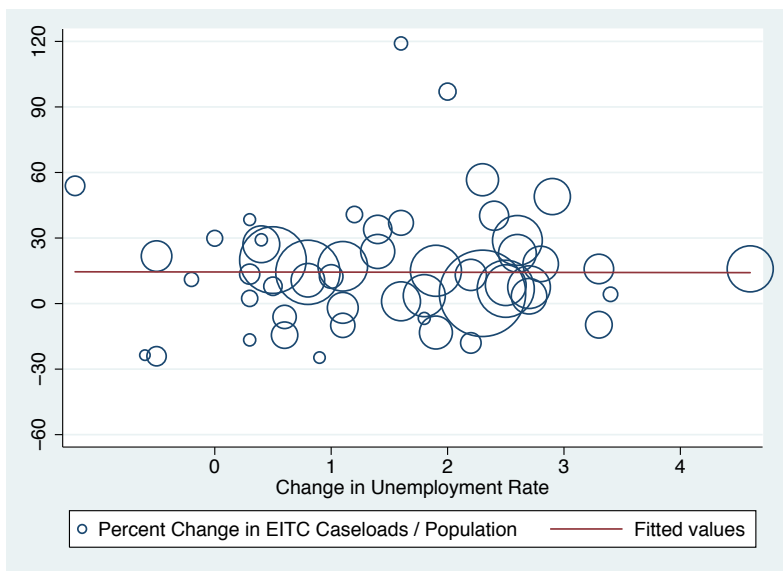

(c) Single with Children

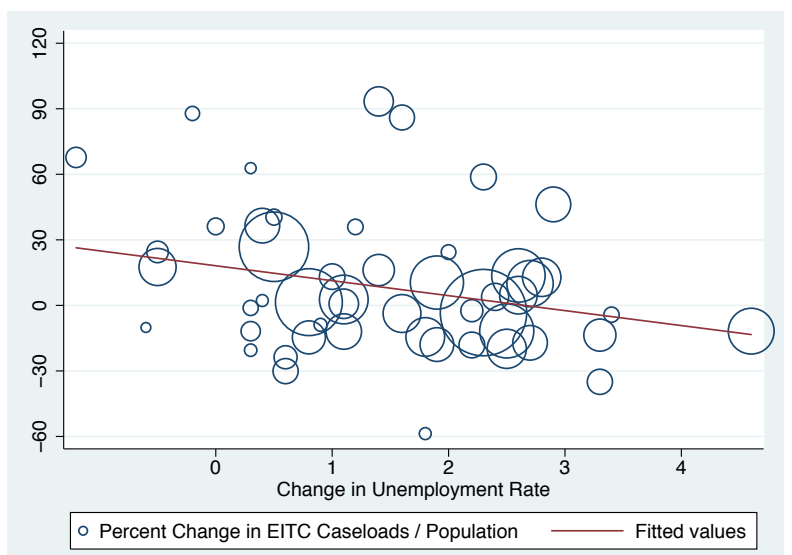

(b) Childless

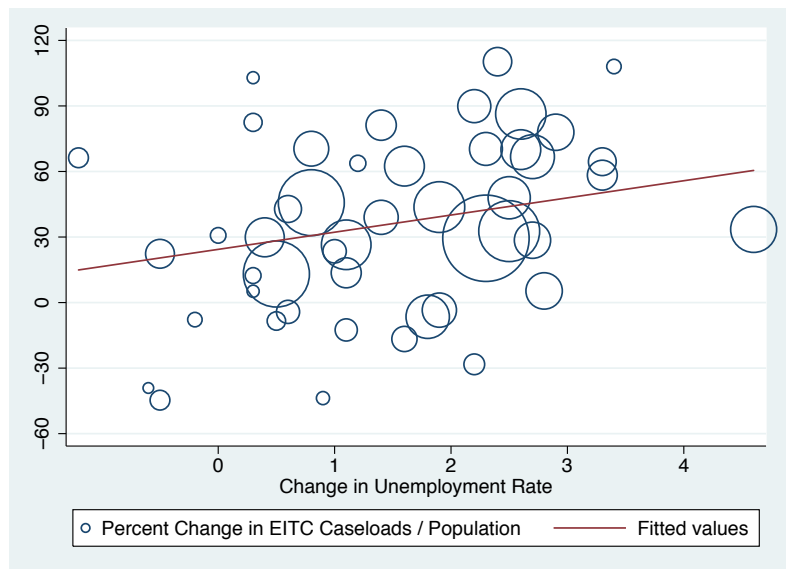

(d) Married with Children

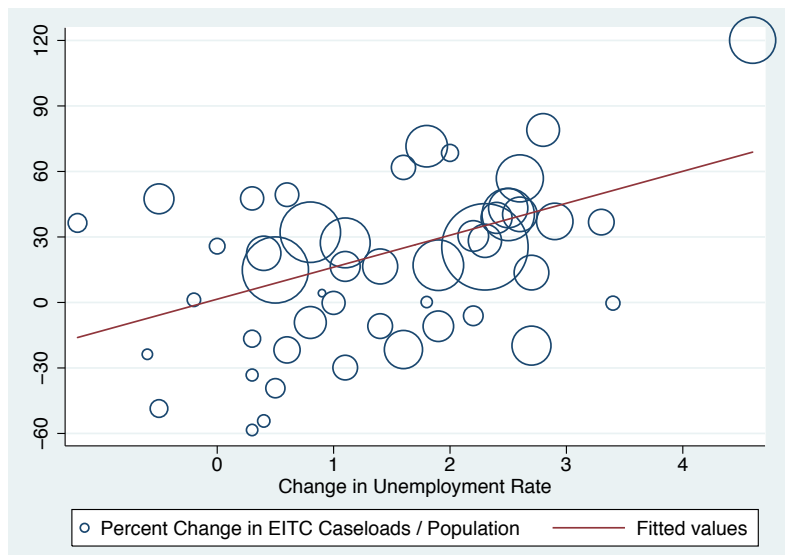

Notes: Data from the 2000 and 2008 Statistics of Income. The sample excludes high-income earners, individuals living abroad, late filers and married couples filing separately. Unemployment rates are from the BLS. Circle sizes are proportional to the population of potential filers in each cell, calculated with CPS ASEC data. In order to present results on the same scale, we drop observations where the percent change in EITC caseloads divided by population is larger than 130. 


\section{A Appendix: Further Results}

Table A.1: Effects of Unemployment Rate on EITC Caseloads and Expenditures, by Marital Status and Number of Children

\begin{tabular}{|c|c|c|c|c|c|c|}
\hline & \multicolumn{3}{|c|}{ Single } & \multicolumn{3}{|c|}{ Married } \\
\hline & $\begin{array}{l}(1) \\
\text { Zero }\end{array}$ & $\begin{array}{l}(2) \\
\text { One }\end{array}$ & $\begin{array}{c}(3) \\
\text { Two or More }\end{array}$ & $\begin{array}{l}(4) \\
\text { Zero }\end{array}$ & $\begin{array}{l}(5) \\
\text { One }\end{array}$ & $\begin{array}{c}(6) \\
\text { Two or More }\end{array}$ \\
\hline \multicolumn{7}{|l|}{ A: EITC Caseloads } \\
\hline Unemployment Rate & $\begin{array}{l}0.003^{* *} \\
(0.001)\end{array}$ & $\begin{array}{l}-0.012 \\
(0.017) \\
\end{array}$ & $\begin{array}{l}-0.005 \\
(0.015)\end{array}$ & $\begin{array}{l}-0.001 \\
(0.001)\end{array}$ & $\begin{array}{l}0.007^{*} \\
(0.004)\end{array}$ & $\begin{array}{c}0.010^{* * *} \\
(0.003) \\
\end{array}$ \\
\hline Mean Y & 0.071 & 0.814 & 0.906 & 0.015 & 0.134 & 0.150 \\
\hline Percent Impact (\%) & 4.4 & -1.5 & -0.5 & -3.8 & 5.5 & 6.7 \\
\hline Observations & 663 & 663 & 663 & 663 & 663 & 663 \\
\hline \multicolumn{7}{|l|}{ B: EITC Expenditures } \\
\hline Unemployment Rate & $\begin{array}{c}0.6 \\
(0.4)\end{array}$ & $\begin{array}{l}-36.1 \\
(39.3)\end{array}$ & $\begin{array}{c}-7.9 \\
(51.6)\end{array}$ & $\begin{array}{l}-0.2 \\
(0.3)\end{array}$ & $\begin{array}{l}11.0 \\
(7.2)\end{array}$ & $\begin{array}{l}25.6^{* *} \\
(10.1)\end{array}$ \\
\hline Mean Y & 17.9 & 1647.3 & 2899.1 & 3.9 & 239.2 & 407.5 \\
\hline Percent Impact (\%) & 3.5 & -2.2 & -0.3 & -4.6 & 4.6 & 6.3 \\
\hline Observations & 663 & 663 & 663 & 663 & 663 & 663 \\
\hline
\end{tabular}

Notes: Data are from the 1996-2008 Statistics of Income, with denominators measuring the number of potential tax filers from the CPS ASEC. The sample excludes high-income earners, individuals living abroad, late filers and married couples filing separately. The dependent variables are total EITC caseloads and real EITC expenditures (\$2008), both divided by the total population of potential filers in each cell. All regressions include controls for state and year fixed effects. The results are weighted by the population of potential filers in each cell. Standard errors are clustered by state and shown in parentheses. $* \mathrm{p}<0.10,{ }^{* *} \mathrm{p}<0.05, * * * \mathrm{p}<0.01$. 
Table A.2: Asymmetric Effects of Unemployment Rate on EITC Caseloads, Expenditures and Tax Filers

\begin{tabular}{lccc}
\hline \hline & $(1)$ & $(2)$ & $(3)$ \\
& No Kids & Kids, Single & Kids, Married \\
\hline \hline A: EITC Caseloads & & & \\
UR ${ }^{*}$ Expansion & $0.003^{*}$ & -0.004 & $0.010^{* * *}$ \\
& $(0.002)$ & $(0.014)$ & $(0.003)$ \\
$\mathrm{UR}^{*}$ Recession & $0.003^{*}$ & -0.008 & $0.009^{* * *}$ \\
& $(0.001)$ & $(0.013)$ & $(0.003)$ \\
\hline P-Value Rec=Exp & 0.453 & 0.181 & 0.377 \\
Observations & 1326 & 1326 & 1326 \\
& & & \\
\hline B: EITC Expenditures & & & \\
\hline UR ${ }^{*}$ Expansion & 0.622 & -17.249 & $21.575^{* * *}$ \\
UR $*$ Recession & $(0.490)$ & $(42.354)$ & $(6.776)$ \\
& 0.543 & -21.852 & $20.678^{* * *}$ \\
\hline P-Value Rec=Exp & $(0.473)$ & $(39.002)$ & $(6.700)$ \\
Observations & 0.513 & 0.566 & 0.577 \\
& 1326 & 1326 & 1326 \\
\hline C: Tax Filers & & & \\
UR ${ }^{*}$ Expansion & $-0.017^{* * *}$ & $-0.019^{*}$ & 0.003 \\
UR * Recession & $(0.006)$ & $(0.011)$ & $(0.006)$ \\
& $-0.016^{* * *}$ & $-0.019^{*}$ & 0.002 \\
\hline P-Value Rec=Exp & $(0.006)$ & $(0.010)$ & $(0.006)$ \\
Observations & 0.343 & 0.918 & 0.889 \\
\hline \hline
\end{tabular}

Notes: Data are from the 1996-2008 Statistics of Income, with denominators measuring the number of potential tax filers from the CPS ASEC. The sample excludes high-income earners, individuals living abroad, late filers and married couples filing separately. The dependent variables are total EITC caseloads, real EITC expenditures (\$2008) and total filers, all divided by the total population of potential filers in each cell. Expansion (recession) years are defined as years in which a state experienced a decrease (increase) in the state unemployment rate. All regressions include controls for demographic characteristics, as well as state and year fixed effects. The results are weighted by the population of potential filers in each cell. Standard errors are clustered by state and shown in parentheses. ${ }^{*} \mathrm{p}<0.10,{ }^{* *} \mathrm{p}<0.05,{ }^{* * *} \mathrm{p}<0.01$. 
Table A.3: Sensitivity to Definition of Population

\begin{tabular}{|c|c|c|c|}
\hline & $\begin{array}{c}(1) \\
\text { No Kids }\end{array}$ & $\begin{array}{c}(2) \\
\text { Kids, Single }\end{array}$ & $\begin{array}{c}(3) \\
\text { Kids, Married } \\
\end{array}$ \\
\hline \multicolumn{4}{|l|}{ A: EITC Caseloads } \\
\hline a) Kids: 18 and younger & $\begin{array}{l}0.002^{*} \\
(0.001)\end{array}$ & $\begin{array}{l}-0.009 \\
(0.014)\end{array}$ & $\begin{array}{c}0.010^{* * *} \\
(0.003)\end{array}$ \\
\hline b) Kids: 19 and younger, or 24 and FT students & $\begin{array}{l}0.002^{*} \\
(0.001)\end{array}$ & $\begin{array}{l}-0.005 \\
(0.014)\end{array}$ & $\begin{array}{c}0.009^{* * *} \\
(0.003)\end{array}$ \\
\hline c) Kids: b) and disabled, citizens only & $\begin{array}{l}0.002^{*} \\
(0.001)\end{array}$ & $\begin{array}{l}-0.009 \\
(0.014)\end{array}$ & $\begin{array}{c}0.010^{* * *} \\
(0.003)\end{array}$ \\
\hline d) Kids: b) and disabled, and filers maximization & $\begin{array}{c}0.003^{*} \\
(0.001)\end{array}$ & $\begin{array}{l}-0.007 \\
(0.011)\end{array}$ & $\begin{array}{c}0.009^{* * *} \\
(0.003)\end{array}$ \\
\hline \multicolumn{4}{|l|}{ B: EITC Expenditures } \\
\hline a) Kids: 18 and younger & $\begin{array}{c}0.4 \\
(0.4)\end{array}$ & $\begin{array}{l}-26.7 \\
(42.9)\end{array}$ & $\begin{array}{c}21.7^{* * *} \\
(7.3)\end{array}$ \\
\hline b) Kids: 19 and younger, or 24 and FT students & $\begin{array}{c}0.4 \\
(0.5)\end{array}$ & $\begin{array}{l}-17.1 \\
(40.8)\end{array}$ & $\begin{array}{c}20.7^{* * *} \\
(6.8)\end{array}$ \\
\hline c) Kids: b) and disabled, citizens only & $\begin{array}{c}0.4 \\
(0.5)\end{array}$ & $\begin{array}{l}-21.6 \\
(39.8)\end{array}$ & $\begin{array}{c}21.7^{* * *} \\
(6.6)\end{array}$ \\
\hline d) Kids: b) and disabled, and filers maximization & $\begin{array}{c}0.5 \\
(0.5)\end{array}$ & $\begin{array}{l}-18.9 \\
(34.1)\end{array}$ & $\begin{array}{c}19.8^{* * *} \\
(6.4)\end{array}$ \\
\hline Observations & 1326 & 1326 & 1326 \\
\hline
\end{tabular}

Notes: Data are from the 1996-2008 Statistics of Income, with denominators measuring the number of potential tax filers from the CPS ASEC. The sample excludes high-income earners, individuals living abroad, late filers and married couples filing separately. The dependent variables are total EITC caseloads and real EITC expenditures (\$2008), both divided by the total population of potential filers in each cell. All regressions include controls for state and year fixed effects. The results are weighted by the population of potential filers in each cell. Standard errors are clustered by state and shown in parentheses. ${ }^{*} \mathrm{p}<0.10,{ }^{* *}$ $\mathrm{p}<0.05, * * * \mathrm{p}<0.01$. 